\title{
Sedimentology, chemostratigraphy, and stromatolites of lower Paleoproterozoic carbonates, Turee Creek Group, Western Australia
}

\section{Citation}

Martindale, Rowan C., Justin V. Strauss, Erik A. Sperling, Jena E. Johnson, Martin J. Van Kranendonk, David Flannery, Katherine French, et al. 2015. "Sedimentology, Chemostratigraphy, and Stromatolites of Lower Paleoproterozoic Carbonates, Turee Creek Group, Western Australia." Precambrian Research 266 (September): 194-211. doi:10.1016/ j.precamres.2015.05.021.

\section{Published Version}

doi:10.1016/j.precamres.2015.05.021

\section{Permanent link}

http://nrs.harvard.edu/urn-3:HUL.InstRepos:27727027

\section{Terms of Use}

This article was downloaded from Harvard University's DASH repository, and is made available under the terms and conditions applicable to Open Access Policy Articles, as set forth at http:// nrs.harvard.edu/urn-3:HUL.InstRepos:dash.current.terms-of-use\#OAP

\section{Share Your Story}

The Harvard community has made this article openly available. Please share how this access benefits you. Submit a story. 
1 Sedimentology, chemostratigraphy, and stromatolites of lower Paleoproterozoic

2 carbonates, Turee Creek Group, Western Australia

4 Rowan C. Martindale ${ }^{\text {a, b, }{ }^{*}, J^{\prime}}$ Justin V. Strauss ${ }^{\text {c }}$, Erik A. Sperling ${ }^{\text {c }}$, Jena E. Johnson ${ }^{\text {d }}$,

5 Martin J. Van Kranendonk ${ }^{\mathrm{e}}$, David Flannery ${ }^{\mathrm{f}, \mathrm{g}}$, Katherine French ${ }^{\mathrm{h}}$, Kevin Lepot ${ }^{\mathrm{i}}$, Rajat

6 Mazumder $^{\mathrm{j}}$, Melissa S. Rice ${ }^{\mathrm{d}, \mathrm{k}}$, Daniel P. Schrag ${ }^{\mathrm{c}}$, Roger Summons ${ }^{\mathrm{h}}$, Malcolm Walter

$7 \quad$ f, John Abelson ${ }^{1}$, Andrew H. Knoll ${ }^{\text {a, c }}$

8

$9{ }^{a}$ Department of Organismic and Evolutionary Biology, Harvard University, 26 Oxford

10 Street, Cambridge, Massachusetts, USA, 02138

$11{ }^{\mathrm{b}}$ Department of Geological Sciences, University of Texas at Austin, 1 University Station

12 C1100, Austin, Texas, USA, 78712

$13{ }^{\mathrm{c}}$ Department of Earth and Planetary Sciences, Harvard University, 20 Oxford Street,

14 Cambridge, Massachusetts, USA 02138

$15{ }^{\mathrm{d}}$ Division of Geological and Planetary Sciences, California Institute of Technology, 1200

16 E California Blvd, Pasadena CA 91125

$17{ }^{\mathrm{e}}$ Australian Centre for Astrobiology and School of Biological Earth and Environmental

18 Sciences, University of New South Wales Australia, Kensington, NSW 2052 Australia

$19{ }^{\mathrm{f}}$ Australian Centre for Astrobiology and School of Biotechnology and Biomolecular

20 Sciences, University of New South Wales Australia, Kensington, NSW 2052 Australia

$21 \mathrm{~g}$ Jet Propulsion Laboratory, California Institute of Technology, 1200 E California Blvd,

22 Pasadena CA 91125 
$23^{\mathrm{h}}$ Department of Earth, Atmospheric, and Planetary Sciences; Massachusetts Institute of 24 Technology, Cambridge, MA 02139, USA.

25 i Laboratoire d'Océanologie et de Géosciences, Université de Lille, CNRS UMR8187,

2659655 Villeneuve d'Ascq, France.

$27{ }^{\mathrm{j}}$ Department of Applied Geology, Faculty of Engineering and Science, Curtin University

28 Sarawak, CDT 250, 98009 Miri, Sarawak, Malaysia.

$29{ }^{\mathrm{k}}$ Melissa S. Rice, Geology Department, Western Washington University, 516 High

30 Street, MS 9080, Bellingham, WA 98225

$31{ }^{1}$ The Agouron Institute, Pasadena, CA 91106, USA

32

$33 *$ Corresponding author

$34 \quad$ e-mail address: Martindale@jisg.utexas.edu

35 Telephone Number: 1-512-475-6439

36 Address: 1 University Station C1100

37 Austin, TX, USA, 78712

38 
40 The ca. $2.45-2.22$ Ga Turee Creek Group, Western Australia, contains carbonate-

41 rich horizons that postdate earliest Proterozoic iron formations, bracket both

42 Paleoproterozoic glaciogenic beds and the onset of the Great Oxidation Event (GOE),

43 and predate ca. 2.2-2.05 Ga Lomagundi-Jatuli C-isotopic excursion(s). As such, Turee

44 Creek carbonate strata provide an opportunity to characterize early Paleoproterozoic

45 carbonate sedimentation and carbon cycle dynamics in the context of significant global

46 change. Here, we report on the stratigraphy, sedimentology, petrology, carbon isotope

47 chemostratigraphy, and stromatolite development for carbonate-rich successions within

48 the pre-glacial part of the Kungarra Formation and the postglacial Kazput Formation.

49 Kungarra carbonate units largely occur as laterally discontinuous beds within a

50 thick, predominantly siliciclastic shelf deposit. While this succession contains thin

51 microbialite horizons, most carbonates consist of patchy calcite overgrowths within a

52 siliciclastic matrix. C-isotopic values show marked variation along a single horizon and

53 even within hand samples, reflecting spatially and temporally variable mixing between

54 dissolved inorganic carbon in seawater and isotopically light inorganic carbon generated

55 via syn- and post-depositional remineralization of organic matter.

56 In contrast, the Kazput carbonates consist of subtidal stromatolites, grainstones,

57 and micrites deposited on a mixed carbonate-siliciclastic shelf. These carbonates exhibit

58 moderate $\delta^{13} \mathrm{C}$ values of $-2 \%$ to $+1.5 \%$ and likely preserve a $\mathrm{C}$-isotopic signature of

59 seawater. Kazput carbonates, thus, provide some of the best available evidence that an

60 interval of unexceptional C-isotopic values separates the Lomagundi-Jatuli C-isotopic

61 excursion(s) from the initiation of the GOE as inferred from multiple sulfur isotopes (loss 
62 of mass independent fractionation). The Kazput Formation also contains unusual, m-scale

63 stromatolitic buildups, which are composed of sub-mm laminae and discontinuous,

64 convex upward lenticular precipitates up to a few $\mathrm{mm}$ in maximum thickness. Laminae,

65 interpreted as microbial mat layers, contain quartz and clay minerals as well as calcite,

66 whereas precipitate lenses consist of interlocking calcite anhedra, sometimes showing

67 faint mm-scale banding. These cements formed either as infillings of primary voids

68 formed by gas emission within penecontemporaneously lithified mats, or as local seafloor

69 precipitates that formed on, or within, surface mats. It is possible that both mechanisms

70 interacted to form the unique Kazput stromatolites. These microbialites speak to a

71 distinctive interaction between life and environment early in the Paleoproterozoic Era.

72

73 Keywords: Turee Creek Group; Kazput Formation; Kungarra Formation; Great

74 Oxidation Event; stromatolite; Lomagundi-Jatuli Event.

75

76 1. Introduction

77 Lower Paleoproterozoic sedimentary rocks record a number of first-order changes

78 in the Earth system, including globally extensive ice sheets, one or more extreme states of

79 the carbon cycle characterized by uniquely high $\delta^{13} \mathrm{C}$ in carbonates, and the initial

80 accumulation of oxygen in the atmosphere and surface oceans (Akin et al., 2013; Asael et

81 al., 2013; Bekker and Holland, 2012; Bekker et al., 2004, 2013; Farquhar et al., 2000;

82 Fralick et al., 2011; Hoffman, 2013; Konhauser et al., 2011; Lyons et al., 2012, 2014;

83 Melezhik and Fallick, 2010; Partin et al., 2013; Planavsky et al., 2012, 2014; Pufahl and

84 Hiatt, 2012; Pufahl et al., 2010, 2011; Reinhard et al., 2013; Scott et al., 2014; Swanner et 
85 al., 2014; and references therein). Co-occurring global glaciation, carbon isotopic

86 variation, and redox change also characterize Neoproterozoic rocks, and for this younger

87 interval, carbonate strata have played an important role in both recording key events and

88 providing context for the interpretation of these events (e.g., Halverson and Shields-Zhou,

89 2011; Johnston et al., 2012). Detailed analyses of platform and shelf carbonates are

90 available for Neoarchean successions [e.g., the Campbellrand/Malmani subgroups of the

91 Transvaal Supergroup, South Africa; (Knoll and Beukes, 2009; and references therein)]

92 and younger Paleoproterozoic rocks [e.g., 2 Ga platform carbonates of the Slave

93 Province, Canada; (Hotinski et al., 2004)]. To date, however, relatively few studies have

94 focused on lower Paleoproterozoic carbonates, despite their potential importance in

95 understanding early Paleoproterozoic evolution and environmental change.

96 The ca. 2.45-2.22 Ga Turee Creek Group, exposed in the Hamersley Range of

97 Western Australia, conformably overlies earliest Paleoproterozoic iron formations,

98 predates the ca. $2.2 \mathrm{Ga}$ onset of the Lomagundi-Jatuli C-isotopic excursion(s), and hosts

99 carbonate and glacially-influenced strata that record onset of the Great Oxidation Event

100 (GOE) (Bekker et al., 2004; Martin et al., 2013; Van Kranendonk and Mazumder, 2015).

101 Thus, these carbonates provide an opportunity to characterize the response of early

102 Paleoproterozoic carbonate deposition and carbon cycle dynamics to significant global

103 change, including the GOE and glaciation. Here, we report on the stratigraphy,

104 sedimentology, carbonate petrology, carbon isotope chemostratigraphy, and stromatolite

105 development in two closely spaced sections of the Kazput Formation of the upper Turee

106 Creek Group. We also report lithological and isotopic data from three parallel

107 stratigraphic sections from the older Kungarra Formation of the lower Turee Creek 
108 Group. Together, these data place carbonate strata of the Turee Creek Group in the

109 context of profound global change following the early oxygenation of Earth's surface

110 environments.

111

\section{2. Geologic Setting}

113 The Turee Creek Group of the Mount Bruce Supergroup is the youngest

114 sedimentary succession within the Hamersley Basin of the Pilbara Craton (Trendall,

115 1990). Turee Creek Group rocks conformably overlie iron formations of the Hamersley

116 Group and sit unconformably beneath sedimentary and volcanic deposits of the Wyloo

117 Group (Fig. 1) (Horwitz, 1982; Thorne, 1990; Thorne and Seymour, 1991; Trendall,

118 1969; Trendall et al., 1983). Initial research suggested conformable relationships

119 throughout the Proterozoic stratigraphy of Western Australia (e.g., Trendall and

120 Blockley, 1970), but continuing stratigraphic and geochronological studies have since

121 identified significant unconformities and deformational events that point to a protracted,

122 but episodic, depositional history spanning more than 330 Myr (Martin et al., 2000; and

123 references therein).

124 Palinspastic reconstructions and basin analysis of upper Hamersley Basin and

125 lower Wyloo Group stratigraphy led Horwitz (1982) to propose a post-Hamersley

126 depositional feature, called the McGrath Trough, that reflects flexural subsidence driven

127 by peripheral or retroarc foreland basin development (Horwitz, 1982; Krapež, 1996;

128 Martin, 1999; Martin et al., 2000; Powell and Horwitz, 1994). The foreland-related

129 tectonostratigraphic sequence most likely involves the Turee Creek and lower Wyloo

130 groups (Martin et al., 2000); however, some authors have argued that it only involves the 
131 Turee Creek Group (e.g., Blake and Barley, 1992; Krapež, 1996) or both the Turee Creek

132 and entire Wyloo groups (e.g., Thorne and Seymour, 1991; Tyler and Thorne, 1990).

133 More recently, Van Kranendonk et al. (2015) suggested the Turee Creek Group was

134 deposited in an intracratonic basin. Regardless of McGrath dynamics, the 3-4 km thick

135 Turee Creek Group records rapid lateral facies change (e.g., Martin et al., 2000 and

136 references therein).

137 The Turee Creek Group consists, in stratigraphic order, of the Kungarra

138 (including the glaciogenic Meteorite Bore Member), Koolbye, and Kazput formations

139 (Fig. 1) (Thorne et al., 1995; Trendall, 1979, 1981). It is bracketed in age by the $2449 \pm 3$

140 Ma Woongarra Rhyolite (Barley et al., 1997) near the top of the underlying Hamersley

141 Group and the $2209 \pm 15$ Ma Cheela Springs Basalt (Martin et al., 1998) low in the

142 unconformably overlying Wyloo Group succession (Fig. 1). Müller et al. (2005)

143 reinterpreted the Cheela Springs date as a reflection of provenance rather than

144 crystallization age, but their U-Pb age on baddeleyite of $2208 \pm 15$ Ma for diorite sills

145 that cut the Turee Creek Group provides an essentially indistinguishable maximum age

146 constraint. The Kungarra Formation of the Turee Creek Group is further constrained to be

147 younger than ca. $2420 \mathrm{Ma}$, based on $\mathrm{U}-\mathrm{Pb}$ ages of detrital zircons in the Meteorite Bore

148 Member (Takehara et al., 2010). Turee Creek Group strata record a broad shallowing-

149 upward profile from deep-water banded iron formation (the Boolgeeda Iron Formation of

150 the underlying Hamersley Group), through fine-grained siliciclastic deposits of the

151 Kungarra Formation, to fluvial and shallow marine strata of the Koolbye and Kazput

152 formations. 
154 challenging, Turee Creek Group strata record two events that guide interbasinal

155 correlation. First, Williford et al. (2011) documented mass independent sulfur isotope

156 fractionation, a proxy for the near-absence of environmental oxygen (Farquhar et al.,

157 2000), in the lower part of the Meteorite Bore Member of the Kungarra Formation. On

158 this basis, the authors suggested that the lower glaciogenic unit of the Meteorite Bore

159 Member, locally in contact with the Boolgeeda Iron Formation, was deposited during the

160 final stages of the GOE, when oxygen levels were still low enough for the development

161 of MIF-S, but sufficiently high for oxidative weathering of continental sulfides and

162 significant sulfur isotope fractionation.

163 The glacial character of the Meteorite Bore Member and a second recently

164 discovered unit of glacial diamictite in the Kungarra Formation provide a means of

165 correlation to other Paleoproterozoic basins (Martin, 1999; Trendall, 1976; Van

166 Kranendonk and Mazumder, 2015). Martin (1999) and Van Kranendonk et al. (2012)

167 pointed to analogous basin histories of the South African Transvaal Supergroup and the

168 Canadian Huronian Supergroup on the basis of similar ca. 2.45 Ga felsic magmatic

169 events followed by glacial episodes and mafic magmatism at ca. 2.2 Ga. Hoffman (2013)

170 suggested a similar global correlation scheme based on the assumption that the GOE, as

171 marked by the disappearance of MIF-S, was a unique event connected in time to a

172 Snowball Earth event (Kirschvink et al., 2000). By this reasoning, disparate sedimentary

173 rocks may be correlated by a single tie point, even though some regions record three

174 glacial events and others only record two. Thus, while it is difficult to assign an exact age

175 to the Turee Creek Group, the glacial history of these strata generally enables broad 
176 correlation to the timing of the Great Oxidation Event (Van Kranendonk and Mazumder, 177 2015).

179 3. Methods

$180 \quad$ Fieldwork for this project was conducted as part of the 2012 Advanced

181 Geobiology Course sponsored by the Agouron Institute. Five stratigraphic sections were 182 measured and sampled from three sites in the Hardey Syncline: the Horseshoe Creek

183 locality of Lindsay and Brasier (2002) (Fig. 1, three sections at site 1) and two Kazput

184 Formation localities, K1 and K2, on the southwest and northeast limbs of a small NNW-

185 SSE-trending anticline in the central part of the Syncline (Fig. 1, sites 2 and 3). The

186 Horseshoe Creek strata were previously described by Lindsay and Brasier (2002) as

187 Kazput Formation, but regional mapping places this section below the Meteorite Bore

188 Member and is thus part of the Kungarra Formation (Fig. 1) (Martin et al., 2000; Van

189 Kranendonk, 2010; Van Kranendonk et al., 2015).

190 At Horseshoe Creek, three parallel stratigraphic columns were measured through

$191 \sim 120 \mathrm{~m}$ of the Kungarra Formation to determine patterns of lateral facies change and

192 geochemical variation ( $\mathrm{HC} 1, \mathrm{HC} 2$, and $\mathrm{HC} 3$ ). The first Kazput section was measured

193 through roughly $140 \mathrm{~m}$ of sedimentary rocks on the west-southwestern limb of the

194 anticline (locality K1), and the second section is a composite stratigraphic column

195 measured across two ridges (roughly $100 \mathrm{~m}$ apart) on the southwestern limb of the

196 anticline (localities K2A, K2B, and K2C). Although the K1 and K2 localities are within a

197 few kilometers of each other, their exact correlation is uncertain due to differing facies

198 development and structural complications. 
Rock samples were collected from each measured section at roughly 1-3 m

200 intervals for geochemical and petrological analysis; samples were cut using a diamond

201 saw, and made into thin sections for petrographic analysis. Thin section blanks were then

202 microdrilled following methods of Kaufman et al. (1990) to obtain fresh powder. Blanks

203 were commonly drilled several times if multiple lithologies or microfacies were present

204 in a single thin section.

205 Carbonate $\delta^{13} \mathrm{C}$ and $\delta^{18} \mathrm{O}$ values for 225 Kazput and 125 Kungarra samples were

206 measured on a VG Optima dual inlet mass spectrometer fed by an Isocarb preparation

207 device in the Harvard University Laboratory for Geochemical Oceanography (see

208 supplementary data). Approximately $1 \mathrm{mg}$ of carbonate powder was dissolved in a

209 common anhydrous phosphoric acid $\left(\mathrm{H}_{3} \mathrm{PO}_{4}\right)$ bath kept at $90^{\circ} \mathrm{C}$ for eight minutes. Carbon

210 dioxide gas was purified cryogenically and measured against an in-house reference gas.

211 No dolomite corrections were applied to the data. Analytical uncertainty was $\pm 0.1 \%$ o

212 (sample:standard ratio of 8:1); results are reported on a Vienna Pee Dee Belemnite scale.

213 Two samples were additionally analyzed using a scanning electron microscope

214 (SEM) with an attached electron dispersive spectrometer (EDS). These small-scale

215 analyses are employed to visualize and compare textures of the two carbonates, as well as

216 to provide a high-resolution map of the stromatolitic laminae from the Kazput Formation.

217 A representative sample from the Kungarra Formation (from $16.25 \mathrm{~m}$ in section HC3)

218 and a stromatolite from the Kazput Formation (KAZS1), were photographed using

219 backscatter detector imaging to highlight compositional contrasts on a Zeiss 1550VP

220 Field Emission SEM in the California Institute of Technology Geological and Planetary

221 Sciences Division Analytical Facility. An Oxford INCA Energy 300 EDS system was 
222 utilized to produce elemental color maps of key elements [Si, $\mathrm{Ca}, \mathrm{C}, \mathrm{Fe}, \mathrm{Al}, \mathrm{Mg}$ ] and

223 these maps were superimposed on backscatter images to highlight different minerals.

224 Elemental analyses have relative accuracy of better than 5\%.

225

\section{4. Results: Sedimentology, facies analysis, and petrography}

227 4.1. Kungarra Formation at Horseshoe Creek

228 Three parallel stratigraphic sections $(\mathrm{HC} 1, \mathrm{HC} 2$, and $\mathrm{HC} 3)$ were measured from

229 the Horseshoe Creek locality; as these sections were only a few hundred meters apart

230 they are shown as a composite section in Fig. 2. The lower $\sim 73.5 \mathrm{~m}$ consists of variably

231 exposed, monotonous grey-green siltstone and shale with occasional thin $(<10 \mathrm{~cm})$

232 lenticular or planar beds of very fine- to fine-grained quartz-rich lithic arenites. These

233 sandstone intervals are locally erosive and host parallel-lamination or occasional very

234 fine ripple cross-lamination with abundant shale partings. Some of the more massive

235 siltstone intervals are locally interspersed with starved ripples of very-fine grained

236 sandstone, but many of the sedimentary structures in the siltstones are masked by a

237 pervasive penetrative cleavage.

238 Numerous discontinuous limestone-bearing beds, $3-70 \mathrm{~cm}$ thick, occur

239 sporadically within the massive siltstone and shale units. Many of these carbonate beds

240 are broadly nodular or irregular in geometry and locally grade into pure siltstone, both

241 vertically and laterally. Some carbonate-rich horizons essentially mimic starved ripples

242 and other sedimentary structures characteristic of surrounding siliciclastic beds (Fig. 3A),

243 consistent with post-depositional diagenetic carbonate precipitation. A diagenetic origin

244 for these discontinuous layers is also supported by petrographic observations and

245 microscale SEM-EDS mapping (Figs. 3C, 4). For example, evidence for diagenetic 
246 carbonate emplacement includes both the restriction of these Kungarra carbonates to

247 lenses and thin layers intermixed with detrital grains (Figs. 3C, 4) and the distribution

248 within these lenses of patchy carbonate in overgrowth and cement-filling textures within

249 a matrix of silt-sized quartz grains, clay minerals, and rare other silicates (Figs. 3C, 4).

250 Figure 4 shows a representative carbonate layer (green) that includes many detrital

251 silicate grains (orange). A diagenetic origin for many Kungarra carbonates is consistent

252 with major element abundances reported by Lindsay and Brasier (2002); on average, Ca

253 and Mg together make up less than $15 \%$ by weight of sampled lithologies, requiring that

254 carbonates are a subordinate component of the samples.

255 A few limestone beds from the Kungarra Formation are more continuous,

256 relatively pure, and either irregularly laminated or clearly stromatolitic. In particular, a

257 distinct stromatolite unit occurs from $\sim 33.9-34.4 \mathrm{~m}$ in section $\mathrm{HC} 3$, which progresses

258 from $\sim 10 \mathrm{~cm}$ of brown-yellow-colored irregular crinkly lamination with interstitial

259 micrite fill into $\sim 25 \mathrm{~cm}$ of discrete $\sim 70 \mathrm{~cm}$ wide elongate stromatolites. These structures

260 are draped by peach-colored dolomicrite and transition into two distinct layers of

261 brownish-white $\sim 15-30 \mathrm{~cm}$ thick domal stromatolites (Fig. 3B) separated by a horizon of

$262 \quad 1-4 \mathrm{~cm}$ wide and $\sim 10 \mathrm{~cm}$ tall, high-inheritance digitate stromatolites. The upper $2-5 \mathrm{~cm}$

263 of the stromatolitic interval is irregular, with local rip-up clasts. Laterally, this

264 stromatolitic interval becomes poorly developed; at section $\mathrm{HC} 2$, only the irregular

265 carbonate laminae and small domal stromatolites occur (Fig. 3B), and at section $\mathrm{HC} 1$ this

266 unit becomes indistinguishable from other thin carbonate units. The only other location in

267 this section with similar stromatolitic features occurs at $\sim 176 \mathrm{~m}$; however, this microbial

268 unit is poorly developed and much thinner $(\sim 10 \mathrm{~cm})$. Unlike the carbonate overgrowths in 
269 the siltstone units, these carbonate units were likely primary (although they have since

270 been recrystallized). Thus the carbonate-rich units at Horseshoe Creek reflect both

271 original carbonate sediments as well as later carbonate overgrowths of siliciclastics.

272 The upper $\sim 172 \mathrm{~m}$ of the Horseshoe Creek section broadly coarsens upwards into

273 a siliciclastic succession dominated by very fine- to fine-grained sandstone. These strata

274 generally transition from green-grey siltstone and argillite with abundant starved ripples,

275 parallel lamination, ripple cross-lamination, and minor carbonate horizons into a

276 succession dominated by very thin- to thin-bedded quartz-rich lithic arenite and

277 sublitharenite with abundant shale partings. One can distinguish clear smaller-scale 1-5

$278 \mathrm{~m}$ thick coarsening upwards packages of siltstone and shale into very-fine to fine-grained

279 sandstone, which are superimposed on the broader coarsening upwards sequence on the 280 formation scale.

281

282 4.2. Kazput Formation, NW Hardey Syncline

283 4.2.1. Kazput Section \#1 (K1)

284 The K1 section (Figs. 5A, 6) was measured on the NE-dipping flank of a NNW-

285 SSE-striking anticline in the southeastern part of the Hardey Syncline (locality 3 on Fig.

286 1). The base of this section is covered by alluvium, so its relationship to the underlying

287 Koolbye Formation is unclear. The section begins with a prominent bench of dark grey

288 parallel-laminated limestone, about $1.5 \mathrm{~m}$ thick (Fig. 5B), that is overlain by $\sim 6 \mathrm{~m}$ of

289 sandy limestone with evidence for soft-sediment deformation. The carbonate strata

290 become increasingly sand-rich and dolomitic upsection until, by $\sim 16.5 \mathrm{~m}$, they are

291 dominated by medium-bedded brown dolomitic sandstone. The outcrop then disappears 
292 into cover for $\sim 30$ meters, but thin-bedded, often calcareous, sandstone horizons are

293 occasionally visible in subcrop (Fig. 5A). Continuous outcrop reappears at $52.5 \mathrm{~m}$, again

294 consisting of interbedded finely laminated calcareous sandstone and brown

295 dolograinstone. The overlying $30 \mathrm{~m}$ consists of brown-weathering (white on fresh

296 surface), coarsely recrystallized dolomite with no visible sedimentary structures. At 86.8

$297 \mathrm{~m}$ the recrystallization fabric disappears and dolostone displays crinkly lamination and

298 roll-up structures that resemble microbially influenced sedimentary structures. In

299 addition, interbedded chert-replaced rip-ups and intraformational conglomerates occur

300 with other indicators of traction load deposition, including ripple and trough cross-

301 stratified dolograinstone, channelized grainstone, and thin channelized sandstone lenses

302 (Fig. 5C). Starting at $116.7 \mathrm{~m}$, the section becomes dominated by wavy laminated

303 dolomite, with abundant pisoids and oncoids (up to a $\mathrm{cm}$ in diameter), and domal

304 stromatolites up to $30-50 \mathrm{~cm}$ wide. A small fault cuts the section at $\sim 127.5 \mathrm{~m}$ rendering

305 thickness measurements of the uppermost part of the succession less reliable. At a

306 minimum, an additional $10 \mathrm{~m}$ of small conical stromatolites, oncoids, and massive grey

307 dolomite cap the section. Pervasive recrystallization of Kazput Formation carbonates

308 dominates petrographic fabrics, but the interlocking calcite euhedra still preserve mm-

309 scale features such as bedding lamination, coated grains, and ooids.

310

311 4.2.2 Kazput Section \#2 (K2)

312 The K2 composite section (Figs. 7A, 8, 9) was measured on the SW-dipping flank

313 of the anticline in the central part of the Hardey Syncline (Locality 2 on Fig. 1). The K2

314 section includes two ridges (Fig. 7A) separated by a small valley filled by alluvial 
315 material (likely the surficial expression of a fault), so the stratigraphy is represented

316 herein as a composite section (K2A, K2A2, and K2B-K2C; Figs. 8, 9).

317 The basal portion of section K2A (Fig. 8) consists of highly fractured and

318 oxidized maroon and olive green siltstone and shale subcrop exposed in a small, south-

319 flowing dry creek bed at the core of the anticline. Fine-grained deposits transition

320 upsection into $\sim 18 \mathrm{~m}$ of olive green to dark grey, parallel laminated to ripple cross-

321 laminated micritic limestone with locally-abundant silt and very fine-grained quartz sand.

322 The basal carbonate-rich strata are thinly bedded and record discrete $\mathrm{mm}$ - to $\mathrm{cm}$-scale

323 alternations between massive and laminated beds that resemble the discrete Bouma C-E

324 subdivisions of distal turbidites. The central $\sim 6 \mathrm{~m}$ of these more carbonate-rich strata are

325 dominated by pure olive green siltstone with minor detrital carbonate, and the upper 5-6

$326 \mathrm{~m}$ of these strata record the local development of hummocky cross-stratification and

327 occasional stoss-preservational ripple cross-lamination in the silty limestone deposits.

328 The upper $\sim 45 \mathrm{~m}$ of section K2A consists of a broad coarsening-upwards package of

329 olive green to dark grey siltstone and argillite and minor thin-bedded light brown very-

330 fine- to fine-grained quartz sandstone (Fig. 7B). The sandstone beds generally display

331 evidence for subtle scouring of underlying siltstone and argillite intervals and the units

332 are dominated by hummocky and swaley cross-stratification. Sedimentary structures in

333 the siltstone and argillite strata are difficult to discern due to a pervasive penetrative

334 cleavage, but they occasionally contain thin $(<5 \mathrm{~cm}$ thick $)$ stringers of nodular and planar

335 micritic limestone. The silica- and carbonate-cemented sandstones of the Kazput

336 Formation can generally be classified as quartz-rich sublitharenites (Martin et al., 2000), 
337 but they are mostly dominated by moderately sorted and subrounded to angular

338 monocrystalline quartz sand with minor lithics, chert, and a pervasive chloritic matrix.

339 Since the upper part of section K2A was exposed on a prominent dip slope that

340 projected into a small, faulted alluvial valley, a parallel section was measured to the

341 northwest on the other side of the structure, section K2A2 (Fig. 8). A $\sim 6 \mathrm{~m}$ thick package

342 of pure olive green siltstone was used to trace the section over the projected small fault

343 horizon. This section begins with $\sim 17 \mathrm{~m}$ of dark grey-green siltstone and argillite that

344 progressively becomes increasingly carbonate rich. Thin (2-3 cm thick) stringers of

345 nodular to stratiform, silty micritic limestone thicken upsection into parallel-laminated

346 and ripple cross-laminated beds up to $10 \mathrm{~cm}$ thick. These silty limestone deposits are

347 abruptly overlain by $\sim 4 \mathrm{~m}$ of peach-orange to blue-grey-colored fine-grained

348 dolograinstone with abundant ripple cross-lamination and minor detrital silt and quartz

349 sand. Locally, there are thin $(<20 \mathrm{~cm})$ horizons with irregular and wavy lamination that

350 resemble microbial carbonates. The upper portion of this small section becomes heavily

351 dolomitized, although there are multiple horizons with crenulated or wavy laminae and

352 intervals of detrital silt and quartz sand that form discrete lenses and stringers within the

353 carbonate laminae. A massive, light bluish-grey colored dolostone horizon was used to

354 trace this section over to section K2B.

355 Section K2B forms the base of a large hill and K2B/C comprises over $65 \mathrm{~m}$ of

356 interbedded carbonate and siliciclastic deposits with some evidence for synsedimentary

357 slumping and faulting (Figs. 7A, D, 9). The lowermost $21 \mathrm{~m}$ of K2B strata are composed

358 of silty to fine-grained sandy limestone with mm-scale parallel lamination, ripple cross-

359 lamination, and low-angle bedding truncations (Fig. 7B) interbedded with two carbonate- 
360 dominated units: a) fine-grained micritic limestones with wavy laminae, crenulated

361 laminae, and small slumps from syn-sedimentary faults; and b) finely-laminated silty to

362 sandy carbonates with low angle hummocky and swaley cross stratification (Fig. 7C).

363 The wavy laminated carbonates often form thin (up to a few $\mathrm{cm}$ ) stromatolites, which can

364 follow relict topography (Fig. 10B) or become contorted, folded, or faulted (syn-

365 sedimentary). These cm-scale stromatolite layers become thicker and well developed

366 higher in the section. Above the interbedded silty and stromatolitic carbonates is a thick

$367(\sim 15 \mathrm{~m})$ interval of well-sorted, fine- to medium-grained sandstone, in decimeter-scale

368 beds with ripple and hummocky cross-stratification.

369 A similar succession of silty and stromatolitic carbonates capped by thick

370 sandstone occurs again in the $\mathrm{K} 2 \mathrm{C}$ section; however, the internal structure of the silty

371 carbonate is more massive than those lower in the section. Higher in the section (around

$37245 \mathrm{~m}$ ), the stromatolitic units develop into thick, well-defined, meter-scale stromatolite

373 domes (Fig. 10). These large stromatolites are commonly contorted and occasionally cut

374 by neptunian dykes (e.g. Fig. 10E). Interbedded with and above the large stromatolitic

375 domes are wave-rippled and hummocky cross-stratified silty sandstones. Beds are often

376 amalgamated, making bedding thickness difficult to discern. A further silty sandstone at

377 the top of the section is distinguished by carbonate intraclasts one centimeter to several

378 meters in length and typically rounded or tabular in shape (Fig. 9). The clasts consist of

379 stromatolites and other carbonate lithologies observed lower in the section, as well as

380 recrystallized oolitic grainstones that broadly link the two measured Kazput sections.

\section{5. Results: Carbon isotope chemostratigraphy}


385 samples distributed through an estimated $250 \mathrm{~m}$ of stratigraphy at Horseshoe Creek,

386 reported as Kazput Formation but now known to belong to the Kungarra Formation.

387 Their $\delta^{13} \mathrm{C}$ values ranged from -6 to $+2 \%$, varying in sawtooth fashion through the

388 reported section. Our larger sample set $(\mathrm{n}=125)$ is consistent with measurements by

389 Lindsay and Brasier (2002); $\delta^{13} \mathrm{C}$ values for Kungarra carbonates at Horseshoe Creek

390 exhibit a wide range of isotopic values, from $-6.3 \%$ to $+0.5 \%$, with no strong

391 stratigraphic trend (Fig. 2). The $\delta^{18} \mathrm{O}$ values for the same samples range from $-6.15 \%$ to -

$3921.61 \%$, again with no strong trend (see supplemental data). In contrast to Lindsay and

393 Brasier (2002), our denser sampling coverage across multiple spatial scales enables us to

394 detect variations in the carbon isotope results of up to $2 \%$ between lighter (more

395 carbonate) and darker (less carbonate) layers within a single hand sample, as much as 4\%o

396 between samples from closely spaced sections at a single stratigraphic horizon, and

397 equally strong variation between samples spaced stratigraphically only centimeters to a

398 few meters apart (Fig. 2, supplemental data).

400 5.2. Kazput carbonates

$401 \quad$ All $\delta^{13} \mathrm{C}$ values measured for Kazput carbonates in the Hardey Syncline $(\mathrm{n}=252)$

402 fall between $-4.5 \%$ and $+2 \%$, and all but a stratigraphically constrained subset lie

403 between $-0.5 \%$ and $+1.5 \%$ (Figs. $6,8,9$ ). These results are consistent with

404 reconnaissance analyses by Bekker et al. (2002). $\delta^{18} \mathrm{O}$ values range from $-8.13 \%$ to -

$40516.63 \%$, with most values falling between $-15.5 \%$ and $-16.5 \%$ (see supplemental data). 
407 the last data point before the prominent covered interval is more moderate at $0.7 \%$.

408 Above the covered interval, $\delta^{13} \mathrm{C}_{\text {carb }}$ values are again depleted (-3\%) but quickly return to

409 values between 0 and $1 \%$ for the remainder of the section (Fig. 6). The $\delta^{13} \mathrm{C}_{\text {carb }}$ signature

410 of section $\mathrm{K} 2$ begins much like that of $\mathrm{K} 1$, with negative values $(-2.5 \%$ to $-1.2 \%$ o $)$ in the

411 lowermost $10 \mathrm{~m}$ (K2A, Fig. 8) followed by values that fluctuate around 0\%o (K2A and

412 K2A2, Fig. 8). Higher in the section (K2B and K2C), C-isotopic values generally

413 fluctuate between ca. 0.5 and $1.5 \%$, with a few more negative values interspersed

414 through the sections (Fig. 9). Variations of up to $1 \%$ among carbonate intraclasts at the

415 top of the section likely reflect the heterogeneous stratigraphic levels from which the

416 intraclasts and carbonate blocks were sourced.

417 Petrographic subsampling of stromatolites at 46-47 m of K2C shows limited

418 isotopic variation among microfacies, with stromatolitic carbonates slightly heavier than

419 the carbonate-rich clastics that overlie the stromatolites (Fig. 9). As might be predicted

420 when ambient waters are strongly oversaturated with respect to calcite and aragonite

421 (Bergmann et al., 2013), carbonates within stromatolites differ little from encompassing

422 laminae in both their carbon and oxygen isotope values (Fig. 9). The analyzed Kazput

423 carbonates do not record the extreme ${ }^{13} \mathrm{C}$ enrichment that defines the younger

424 Lomagundi-Jatuli event.

\section{6. Results: Kazput stromatolites}

427 The most notable sedimentary features of the Kazput carbonates are m-scale 428 domal stromatolites in section K2B/C (Fig. 10). These stromatolites appear to have 
429 nucleated on erosional surfaces within underlying siliciclastic units and were, in turn,

430 episodically buried by further influx of sands that locally display hummocky cross-

431 stratification. The resulting microbialites can be as thin as a centimeter (Fig 10B),

432 suggesting only a limited time for accretion between inundation events, to as much as 1.5

433 meters thick (Fig 10A).

$434 \quad$ Two fabrics make up the Kazput stromatolites (see Section 7.3 for genetic

435 interpretations): wavy to crenulated siliciclastic laminae, 30 to $400 \mu \mathrm{m}$ thick, that are

436 continuous on the scale of a single dome, and interbedded, convex upward, lenticular

437 carbonates that are generally discontinuous on a $\mathrm{mm}$ to $\mathrm{cm}$-scale and are common or

438 absent in alternating zones (Fig. 10). The discrete fabrics are clear in both optical

439 microscopic view (Fig. 11) and in elemental maps using SEM (Fig. 12). Lamina-rich

440 zones tend to be $<1 \mathrm{~cm}$ to about $2 \mathrm{~cm}$ thick, whereas zones rich in lenticular carbonate

441 vary from $<1 \mathrm{~cm}$ to, more commonly, $10-15 \mathrm{~cm}$ thick. Because silicate laminae are more

442 resistant to erosion than carbonate lenses, the broad mesoscale fabric of the stromatolites

443 is best observed on weathered surfaces; lamina-rich zones are darker brown and more

444 resistant, carbonate-rich zones are grey or lighter tan and more recessive (Fig. 10). For

445 the most part, lenticular carbonates occur within 5-15 mm long convex-upward mini-

446 domes bounded by laterally linked laminae that tend to be continuous across the surfaces

447 on which they occur. In some layers, lenses extend laterally for several $\mathrm{cm}$ along bedding

448 planes (Fig 10D); however, these occurrences are rare. Most of the stromatolitic

449 structures are irregular, and some show evidence of plastic deformation (folds and

450 slumps). At a few horizons, however, more or less regular, laterally linked columns 
451 develop either locally (Fig. 10F) or across a stromatolitic dome surface (Fig 10D);

452 columns are 5-8 $\mathrm{cm}$ wide and $2-10 \mathrm{~cm}$ high.

453 At the microscopic scale, laminae contain an admixture of several minerals,

454 including equant calcite anhedra, $10-25 \mu \mathrm{m}$ in maximum dimension; quartz silt; clay

455 minerals (commonly chloritized, but also including Mg-rich species); and small opaque

456 euhedra, probably originally diagenetic pyrite, but now altered to iron oxides (Figs. 11,

457 12). While clays can form authigenically within microbialites (Konhauser and Urrutia,

458 1999; Léveillé et al., 2000) the presence of abundant fine-grained quartz grains and other

459 detrital material indicates the incorporation of suspension load siliciclastics, even when

460 traction load sands were absent. Organic carbon inclusions also occur sporadically

461 throughout the K2 stromatolites; these appear as black spots on the composite elemental

462 map or red spots on the carbon map in Figure 12.

463 Lenticular units generally consist of interlocking calcite anhedra $25-100 \mu \mathrm{m}$ in

464 maximum dimension. Pyrite, reduced carbon, and clay minerals also occur in these zones,

465 although at low abundances (Fig. 12). The coarsely crystalline carbonates reflect

466 pervasive diagenetic and/or metamorphic recrystallization, but mm-scale banding is

467 preserved locally (Fig 11C). Crystals are smaller in these banded carbonates, generally

468 less than $25 \mu \mathrm{m}$, and discrete zones are defined by both larger and smaller crystals

469 (lighter and darker zones in Fig 11C), as well as a faint tendency for smaller crystals to be 470 oriented along laminae surfaces.

471 The stromatolites form irregular, m-scale domes on flat-lying surfaces or arches

472 over relict seafloor relief; local reorientation and folding indicate slumping during or

473 shortly after accretion. Like the smaller scale fabrics, at the decimeter to meter scale these 
474 stromatolitic domes are variable in shape, but heritability is much higher. The domes are

475 capped by and often interbedded with hummocky cross-stratified sandstones. Clastic-

476 filled neptunian dykes occur sporadically through the section (Fig. 10E). The dykes

477 typically cut at a high angle through the undeformed stromatolite layers, but can run

478 parallel to lamination in cement-poor intervals. In aggregate, these features are plausibly

479 explained by a composite structure that combined rigid penecontemporaneous cements

480 with more plastic silt- and clay-rich laminae, as discussed below.

\section{7. Discussion}

\section{$483 \quad 7.1$ Kungarra carbonates}

484 Broadly, Kungarra Formation strata record a major coarsening upwards sequence 485 from banded iron formation and starved basin deposits of the underlying Boolgeeda Iron

486 Formation through glaciomarine deposits of the Meteorite Bore Member and finally into

487 tidal flat, beach, and fluvial deposits of the overlying Koolbye Formation (Mazumder et

488 al., 2015). The measured Horseshoe Creek section (Fig. 2) captures a small component of

489 this broad coarsening upwards trend. The abundance of fine-grained suspension deposits

490 interbedded with starved ripple and planar ripple cross-laminated sandstone intervals

491 most likely represents subtidal deposition between storm and fair weather wave base.

492 This is consistent with the limited development of stromatolites. The lack of directly

493 overlying shoreface deposits suggests that deposition was predominantly in an offshore

494 setting, although the increase in sandstone intervals and the broad coarsening upwards

495 trend in the upper $\sim 25 \mathrm{~m}$ of the measured section is diagnostic of progradation. Given

496 these features, we suggest these strata were largely deposited in a prodeltaic or mid-outer 
497 shelf environment, broadly consistent with the interpretations of previous workers

498 (Krapež, 1996; Martin et al., 2000; Van Kranendonk et al., 2015).

499 As noted above, Lindsay and Brasier (2002) sampled the carbonate-bearing rocks

500 at Horseshoe Creek, and the highly variable carbon isotope values were interpreted to

501 indicate pronounced carbon cycle variation in the aftermath of the GOE. However,

502 regional mapping has shown that the strata in question lie stratigraphically beneath the

503 Meteorite Bore Member and so are properly assigned to the Kungarra Formation

504 (Krapež, 1996; Martin et al., 2000; Van Kranendonk et al., 2015). Furthermore,

505 stratigraphic field relationships and detailed petrology both suggest that most of these

506 Kungarra carbonates formed during diagenesis, and the marked C-isotopic variation

507 recorded in these rocks confirms this interpretation (Figs $2-4$ ). $\delta^{13} \mathrm{C}$ values of $-6 \%$ are

508 unusual for carbonates of any age and commonly reflect the incorporation of isotopically

509 light carbon into diagenetic carbonates precipitated within sediments (Irwin et al., 1977).

510 Within Lindsay and Brasier's (2002) plotted stratigraphic column, $\delta^{13} \mathrm{C}$ values commonly

511 vary by several per mil from one sample to the next. Our more detailed data set enables

512 us to document large carbon isotopic variations (up to 4\%) within hand samples and

513 between samples from the same stratigraphic horizon (Fig. 2). Such fine-scale spatial and

514 temporal variation is essentially impossible to accommodate in terms of primary C-

515 isotopic signatures reflecting global seawater chemistry.

516 Arguably, the isotopic variation observed at individual horizons in the lower

517 Kungarra Formation of the Horseshoe Creek section reflects diagenetic carbonate

518 precipitation from pore fluids in which dissolved inorganic carbon (DIC) sourced from

519 seawater was variably mixed with inorganic carbon generated by the remineralization of 
520 isotopically light organic matter. In this case, the most positive isotope results represent

521 values closest to the dissolved inorganic carbon (DIC) in seawater. Alternatively, if these

522 units underwent episodic subaerial exposure in the Paleoproterozoic, meteoric waters

523 may have altered the isotopic composition of the strata during early diagenesis.

524 Regardless, the isotopic values from the measured Kungarra Formation from the

525 Horseshoe Creek section by and large do not represent the original isotopic composition

526 of seawater during the time of deposition.

528 7.2. Kazput carbonates

529 Similar to the underlying Kungarra Formation, the $\sim 750 \mathrm{~m}$ thick Kazput

530 Formation records a complex depositional history heavily influenced by local

531 synsedimentary tectonism (Krapež, 1996; Martin et al., 2000; Thorne and Tyler, 1996;

532 Thorne et al., 1995). Numerous $\mathrm{cm}$ to dm scale synsedimentary normal faults in K2B and

$533 \mathrm{~K} 2 \mathrm{C}$ indicate the occurrence of active extensional tectonism during Kazput

534 sedimentation. Furthermore, the large stromatolitic clasts and rip-ups (including m-scale

535 rafts that are clearly transported) in the uppermost K2 facies likely represent seismically-

536 generated breccias (seismites) or the erosion of locally uplifted strata. Given the limited

537 stratigraphic range of this study within the Turee Creek Group, it is difficult to provide

538 more context to the greater basinal or tectonic setting of these strata.

539 Given previous descriptions of the basal Kazput succession as a starved basin

540 marked by distinct carbonate rhythmites (e.g., Krapež, 1996), the Kazput sections

541 described here appear to lie relatively close to the base of the formation. The parallel-

542 laminated and turbiditic silty limestone units that mark the base of the two measured 
543 sections suggest a relatively quiet-water environment. At both localities, the rocks

544 quickly transition upsection into fine-grained siliciclastic units with abundant evidence

545 for storm-generated bedforms, indicative of higher energy/shallower water conditions.

546 The remainder of the measured sections can be interpreted as a broad shallowing upward

547 succession of mixed carbonate and siliciclastic strata. The abundance of fine-grained

548 shale and siltstone interbedded with hummocky and swaley cross-stratification in the

549 central part of the sections suggests subtidal deposition on a storm-dominated shelf

550 between storm and fair weather wave base. The establishment of this subtidal shelf

551 setting was relatively short-lived because both Kazput sections record relatively abrupt

552 shoaling into shallow-water shoreface and platformal settings. This is clearly evidenced

553 by the deposition of thick peritidal to subtidal platformal carbonate dominated by ooids,

554 oncoids, and coarse dolograinstone in section K1 (Fig. 6) and a more complex mixed

555 sandstone-stromatolitic limestone sequence in section K2 (Figs. 8, 9).

556 The striking difference in siliciclastic composition between the upper portions of

557 the two parallel sections ( $\mathrm{K} 1$ and $\mathrm{K} 2$ ) is problematic; however, given the complexity and

558 heterogeneity of along-strike facies and possible proximity to a shoreline, it is reasonable

559 to conclude that their differences are primarily due to proximity to siliciclastic point

560 sources, such as nearby deltaic systems. In fact, section K2 preserves many of the

561 hallmarks of high sedimentation rates in a tectonically active basin, such as thick

562 sequences of stoss-preservational ripple cross-lamination and abundant synsedimentary

563 dykes and soft-sediment deformation. The intimate association of unique stromatolite

564 morphologies and abundant trough cross-stratified sandstone intervals in the upper K2

565 interval also suggests deposition in a shoreface setting subject to periodically high 
566 sedimentation rates. We note that carbonate lithologies differ between sections K1 and

567 K2, with stromatolite development limited to the latter. We cannot rule out the possibility

568 that the two sections are not strictly coeval, but prefer to interpret these facies as

569 contemporaneous expressions of carbonate deposition in a spatially heterogeneous and 570 rapidly developing basin.

571 Unlike the results from the Kungarra Formation carbonates, the Kazput isotope

572 data are interpreted to indicate dominantly primary seawater values. The agreement of

573 values from closely spaced samples and the consistent trends suggest that diagenetic

574 overprinting of the isotopic signal was minimal. Furthermore, no petrographic results

575 suggest secondary calcite overgrowths, which are clearly documented in the Kungarra

576 carbonates (Fig. 3). Thus, the C-isotopic values of -1 to $-3 \%$ in lowermost Kazput

577 carbonates could record transiently low $\delta^{13} \mathrm{C}$ in contemporaneous seawater. Above this

578 horizon, however, values hover between $0.5 \%$ and $1.5 \%$ through the reminder of the

579 succession.

580

581 7.3. Kazput stromatolites

582 The striking m-scale stromatolite domes of the Kazput Formation (Fig. 10) exhibit

583 features that are typically associated with microbial carbonates, but are unique in

584 containing such an abundance of lensoidal calcite precipitates. Laminae in these

585 structures are interpreted as the sedimentary manifestation of mat-building microbial

586 communities. Beyond their general similarity to laminae observed in stromatolites

587 throughout the Proterozoic Eon, a mat origin is supported by at least four observations:

588 (1) the irregular and commonly distorted surfaces of laminae indicate formation by 
589 materials that were both coherent and flexible; (2) quartz silt and, very likely, clay

590 minerals within laminae indicate the trapping and binding of introduced materials; (3)

591 laminae contain a higher concentration of reduced carbon than associated microfabrics,

592 consistent with an origin as mats; and (4) laminae contain localized high concentration of

593 (originally) pyrite, suggesting decay within mats via microbial sulfate reduction. The

594 microbial mats likely nucleated on sandy substrates, forming wrinkled mats (wrinkle

595 structures or laminae) and cm-scale stromatolites (Fig 10B); larger structures resulted

596 from protracted growth between episodes of sand deposition. Based on petrographic and

597 elemental analysis, the quartz silt and clay minerals that are found within the

598 stromatolites indicate that suspension load siliciclastics were continuously deposited on

599 mat surfaces during stromatolite growth.

600 An outstanding question is the extent to which the lenticular carbonates found

601 between laminae formed on, or just beneath, mat surfaces or filled primary voids formed

602 by gas emission within mats. Gas-generated voids occur sporadically throughout the

603 Proterozoic stromatolite record. Their formation generally requires strong but flexible

604 mats populated by filamentous microorganisms, gas generation (e.g., oxygenic

605 photosynthesis, decomposition of organic matter, or methanogenesis), and seawater that

606 is strongly oversaturated with respect to calcium carbonate minerals (e.g., Knoll et al.,

607 2013; Mata et al., 2012). Indeed, primary voids in Archean stromatolites have been

608 interpreted as prima facie evidence for oxygenic photosynthesis at $3 \mathrm{Ga}$ (Bosak et al.,

$6092009,2010)$. The carbonate precipitates do not crosscut microbial laminae, eliminating

610 dissolution and subsequent in-filling as an explanation for the observed textures. 
611 Given that the Kazput stromatolites lie within rocks deposited stratigraphically

612 after the GOE, all aforementioned requirements for the formation and preservation of

613 primary voids appear to have been met locally. The irregular, convex upward

614 morphology of laminae is consistent with this interpretation, as is the orientation of zoned

615 cements in some stromatolites (Fig. 11C, E). However, the lateral extent of discrete

616 cement horizons that occasionally contain clay, pyrite, and reduced carbon flecks also

617 supports the alternative interpretation that the cements are seafloor precipitates formed on

618 or within surface mats (e.g., Fig. 11B). In fact, the two interpretations are not mutually

619 exclusive; if the waters that bathed the Kazput bioherms were strongly supersaturated

620 with respect to calcium carbonate, both void-forming and cementing processes may have

621 been operating during stromatolite accretion.

622 Stromatolites are found widely in late Archean and Paleoproterozoic carbonates,

623 with particularly good descriptions of macro- and microstructure available for late

624 Archean microbialites from the Gamohaan and Frisco formations of the

625 Campbellrand/Malmani succession, South Africa (Sumner, 1997), and lower

626 Paleoproterozoic carbonates from the Fennoscandian Shield (McLoughlin et al., 2013).

627 What differentiates the Kazput stromatolites from most of these (and essentially all

628 younger Proterozoic) structures is their abundance of lenticular carbonate. Microdigitate

629 stromatolites, some of them small microbial structures and others stacked crystal fans

630 (Grotzinger and Knoll, 1999), are particularly widespread in Paleoproterozoic carbonate

631 successions (Medvedev et al., 2005). These structures formed widely across shallow

632 shelves and platforms and reflect a high degree of oversaturation with respect to calcium

633 carbonate minerals. Thus, they are relevant to the interpretation of the Kazput structures, 
634 but differ in lacking the regular interlamination of microbial laminae and precipitates 635 described here.

636 Perhaps the closest approximation of the composite laminar-lenticular Kazput

637 fabric is found in cuspate microbialites from the Campbellrand/Malmani succession

638 (Sumner, 1997) and elsewhere in late Archean carbonates (e.g., Hofmann and Masson,

639 1994; Riding et al., 2014). In these structures, void spaces that originated by the draping

640 of pliant mats across vertical microbial "tent poles" were filled penecontemporaneously

641 by carbonate cement (Sumner, 1997). Locally, stromatolites in the $2720 \pm 5 \mathrm{Ma}$

642 Tumbiana Formation, Fortescue Group, Western Australia, also contain thin, irregular

643 patches of carbonate precipitates, interpreted as lake-floor precipitates (Flannery and

644 Walter, 2012; Lepot et al., 2008, 2009). The Kazput and Tumbiana stromatolites do share

645 some similarities, such as the weathering profile (prominent laminae and recessive

646 cements) and the $\mu \mathrm{m}$-scale banded carbonate domes within carbonate-rich layers;

647 however, there are important distinctions between the two. Kazput stromatolites do not

648 contain halite pseudomorphs, nor is there evidence for the penecontemporaneous erosion

649 of carbonate precipitates, as is clearly evident in the Tumbiana stromatolites (Lepot et al.,

$6502008,2009)$. Furthermore, the Kazput stromatolites cements are largely discrete (mm- to

$651 \mathrm{~cm}$-scale) lenses and typically do not form thick, continuous cement laminae as in the

652 Tumbiana examples. These examples underscore the importance of macroscopic

653 carbonate precipitates in generating fabrics within late Archean/early Paleoproterozoic

654 stromatolites; nonetheless, the specific alternation of particle-binding mats and lenticular

655 carbonate precipitates is, to the best of our knowledge, a unique feature of Kazput 
656 stromatolites in the Hardey Syncline, reflecting a potentially time-limited interaction

657 between the evolving biota and its physical surroundings.

658

659 7.4. Chemostratigraphic comparisons

660 Few carbon isotopic data are available for carbonates that unambiguously lie

661 above Paleoproterozic iron formations but below glaciogenic rocks. Samples from the

662 poorly dated Boxelder Creek Formation, South Dakota (Bekker et al., 2003a) and

663 Polisarka Sedimentary Formation in drill cores from the Kola Peninsula, Russia (Brasier

664 et al., 2013), span a range of $-6 \%$ to $1 \%$. Carbonates of the Gandarela Formation, Brazil,

665 are isotopically similar, but cannot be placed unambiguously relative to Paleoproterozoic

666 ice ages. Post-glacial marbles of the Paleoproterozoic Sauser Group, India, also show C-

667 isotopic values of $-3.1 \%$ to $+2.6 \%$ above a moderately negative basal interval (- $-4.4 \%$ to

$668-7.4 \%$ ) interpreted as a cap carbonate (Mohanty et al., 2015). The most positive C-

669 isotopic values for Kungarra carbonates are consistent with the values reported from

670 other basins, but the uncertainties introduced by diagenetic carbonate precipitation limit

671 what the Kungarra samples can add to discussions about the post-BIF, pre-GOE carbon

672 cycle.

673 On the basis of limited data, Karhu and Holland (1996) hypothesized that the

674 strongly positive carbon isotopic excursion called the Lomagundi-Jatuli event began ca.

$6752.2 \mathrm{Ga}$. Even now, isotopic data are sparse for successions younger than GOE

676 onset/glaciogenic rocks but older than 2200 Ma. Martin et al. (2013) summarized

677 available radiometric constraints on the Lomagundi-Jatuli event, concluding that the

678 event began between $2306 \pm 9 \mathrm{Ma}$ and $2221 \pm 5 \mathrm{Ma}$ and ended between $2106 \pm 8$ and 
$6792057 \pm 1 \mathrm{Ma}$, for a maximum duration of $249 \pm 9$ million years and a minimum duration 680 of $128 \pm 9.4$ million years. The new data presented herein are consistent with these age 681 constraints, and provide no evidence for strongly positive Lomagundi-Jatuli $\delta^{13} \mathrm{C}$ values 682 during deposition of the measured Kazput sections. We recognize, however, that our 683 sections represent a limited proportion of the time interval between Paleoproterozoic ice 684 ages and events commencing at $2200 \mathrm{Ma}$; regionally, Kazput carbonates are separated 685 from the Cheela Springs basalt and its intrusive counterpart (2209 $\pm 15 \mathrm{Ma}$; Martin et al., 686 1998) by thick siliciclastic deposits and a major unconformity (Fig. 1). Thus, while these 687 new data demonstrate that the interval between the GOE onset/glacials and $2200 \mathrm{Ma}$ 688 includes a time where the seawater DIC isotopic composition was unperturbed and 689 similar to modern isotopic values, we cannot rule out the possibility that it also includes 690 short intervals of positive $\mathrm{C}$-isotopic excursions, which are not recorded in the analyzed 691 Kazput Formation sections.

692 Kazput carbonates are isotopically similar to those of well-developed carbonates 693 in the Gandarela Formation, Brazil, where 163 samples show values near 0\% (Bekker et 694 al., 2003b; Maheshwari et al., 2010). The Gandarela carbonates (Babinski et al., 1995) lie 695 stratigraphically above major BIF and below carbonates that show Lomagundi-type ${ }^{13} \mathrm{C}$ 696 enrichment, but the regional stratigraphy contains no glacial diamictites; Bekker et al. 697 (2003b) cite a Pb-Pb date of $2420 \pm 19$ Ma for Gandarela carbonates, but this does not 698 appear in Martin et al.'s (2013) review due to the low confidence in the interpretation of $699 \mathrm{~Pb}-\mathrm{Pb}$ carbonate dates in Proterozoic successions. The well-studied Duitschland 700 Formation, dated indirectly at $2316 \pm 7 \mathrm{Ma}$ by Re-Os on black shale of the possibly 701 correlative Rooihoogte-Timeball Hill Formation (Hannah et al., 2004), bears ${ }^{13} \mathrm{C}$ 
702 enrichments up to $10.1 \%$ in its upper part (Bekker et al., 2001). However, the Mooidraai

703 Dolomite (diagenetic age of $2394 \pm 26 \mathrm{Ma}$, based on carbonate-bound Pb), also in South

704 Africa, appears to have no isotopic anomalies, with $\delta^{13} \mathrm{C}$ values of 0.5 to $1 \%$, more

705 similar to those of the Kazput Formation (Bau et al., 1999). Clearly, tighter radiometric

706 constraints will be necessary to validate interbasinal correlations and accurately

707 reconstruct early Paleoproterozoic carbon cycle dynamics.

709 8. Conclusions

710 This study provides new litho- and chemostratigraphic data for carbonate-bearing

711 intervals of the 2.45-2.22 Ga Turee Creek Group, Western Australia, which spans a

712 pivotal time in Earth history after the deposition of global banded iron formation and

713 across the GOE. Field relationships, petrography, elemental mapping, and C-isotope

714 values reveal that most Kungarra carbonates in the pre-glacial lower part of the Turee

715 Creek Group formed during syndepositional or post-depositional diagenesis; therefore,

716 the abundant and highly negative $\mathrm{C}$-isotopic values within these rocks cannot be

717 interpreted in terms of global carbon cycle dynamics, as previously assumed by Lindsay

718 and Brasier (2002).

719 In contrast, carbonates from the lower part of the uppermost Kazput Formation of

720 the Turee Creek Group - which sits in a globally under-sampled interval above

721 Paleoproterozoic glacial deposits and below an unconformity constrained by the $\sim 2.2 \mathrm{Ga}$

722 Cheela Springs Basalt and associated sills — do appear to record the C isotopic

723 composition of seawater DIC, with consistent $\delta^{13} \mathrm{C}$ values of -2 to $+1.5 \%$. As the lower

724 parts of the Kazput Formation likely represent a relatively brief time interval, it 
725 strengthens a growing body of evidence indicating that the initial geochemical signature

726 of the GOE and the exceptionally positive values of the Lomagundi-Jatuli isotope

727 excursion(s) are separated by one or more intervals of normal C isotopic composition.

728 The moderate C-isotopic values of Turee Creek Group carbonates strengthen the

729 argument that the complex set of processes that drove the onset of the GOE did not

730 include anomalously high proportional rates of organic carbon burial. Of course, as others

731 have noted (e.g., Lyons et al., 2014; and references therein), it is not required that the

732 increase in Paleoproterozoic oxygen concentrations was limited to the brief interval

733 marked by the end of mass-independent $\mathrm{S}$ isotope fractionation, nor that oxygen change

734 was monotonic (Canfield, 2014; Canfield et al., 2013; Lyons et al., 2014). Instead, the

735 MIF-S signature might reflect an interval of atmospheric oxygen accumulation that was

736 neither large nor rapid but crossed an important threshold. One would expect $p \mathrm{O}_{2}$ to

737 continue to rise during the Lomagundi-Jatuli event (e.g., Bekker and Holland, 2012;

738 Kump et al., 2011; Rasmussen et al., 2013), but any increase in oxygen levels driven by

739 extensive organic carbon burial postdates the MIF-S boundary, very likely by tens of

740 millions of years (see also Martin et al., 2013).

741 Beyond the perspective on Paleoproterozoic carbon cycle dynamics provided by

742 the stable carbon isotopic data, Turee Creek Group carbonates host unusual, if not

743 unique, stromatolites that are geobiologically informative. Notably, Kazput stromatolites

744 contain a high volume of precipitated carbonate - indeed, more abundant than the

745 siliciclastic-rich laminae in many horizons (Fig. 10). As noted above, this reflects locally

746 abundant seafloor precipitates and/or penecontemporaneous filling of primary voids

747 formed by microbial gas release. The most comparable structures are precipitate-rich 
748 cuspate Archean microbialites from South Africa (Sumner, 1997) and late Archean

749 Tumbiana stromatolites from Western Australia (Flannery and Walter, 2012; Lepot et al.,

750 2008, 2009). Whatever their proper mechanistic interpretation, the Kazput Formation

751 stromatolites in the Hardey Syncline are morphologically distinct, reflecting a potentially

752 time-limited interaction between the evolving biota and its physical surroundings.

\section{Acknowledgements}

755 We thank R. Shapiro and an anonymous reviewer for constructive comments on

756 an earlier version of this paper. We thank the Agouron Institute for funding the 2012

757 Advanced Geobiology Course to Australia, Henry Goodall and Guy L'Estrange for

758 logistical support, and Sarah Manley for running the carbon isotope analyses. R.

759 Martindale thanks Dr. A. H. Knoll and the NASA Astrobiological Institute for providing

760 postdoctoral funding. J. Strauss and K. French acknowledge NSF graduate research

761 fellowships for funding support. E. Sperling thanks the Agouron Institute for an Agouron

762 Postdoctoral Fellowship. D. Flannery was supported by the University of New South

763 Wales and the Australian Centre for Astrobiology. M. Walter acknowledges a

764 Professorial Fellowship from the Australian Research Council. R. Mazumder is grateful

765 to the University of New South Wales and Agouron Institute for support. M. Van

766 Kranendonk also acknowledges funding support from the University of New South

767 Wales. 


\section{References}

769 Akin, S.J., Pufahl, P.K., Hiatt, E.E., Pirajno, F., 2013. Oxygenation of shallow marine

770 environments and chemical sedimentation in Paleoproterozoic peritidal settings: Frere

771 Formation, Western Australia. Sedimentology 60, 1559-1582.

772 Asael, D., Tissot, F.L.H., Reinhard, C.T., Rouxel, O., Dauphas, N., Lyons, T.W.,

773 Ponzevera, E., Liorzou, C., Chéron, S., 2013. Coupled molybdenum, iron and uranium

774 stable isotopes as oceanic paleoredox proxies during the Paleoproterozoic Shunga Event.

775 Chemical Geology 362, 193-210.

776 Babinski, M., Chemale Jr, F., Van Schmus, W.R., 1995. The $\mathrm{Pb} / \mathrm{Pb}$ age of the Minas

777 Supergroup carbonate rocks, Quadrilátero Ferrífero, Brazil. Precambrian Research 72, $778 \quad 235-245$.

779 Barley, M.E., Pickard, A.L., Sylvester, P.J., 1997. Emplacement of a large igneous

780 province as a possible cause of banded iron formation 2.45 billion years ago. Nature 385 , $781 \quad 55-58$.

782 Bau, M., Romer, R.L., Lüders, V., Beukes, N.J., 1999. Pb, O, and C isotopes in silicified

783 Mooidraai dolomite (Transvaal Supergroup, South Africa): implications for the

784 composition of Paleoproterozoic seawater and 'dating' the increase of oxygen in the

785 Precambrian atmosphere. Earth and Planetary Science Letters 174, 43-57.

786 Bekker, A., Holland, H.D., 2012. Oxygen overshoot and recovery during the early

787 Paleoproterozoic. Earth and Planetary Science Letters 317-318, 295-304.

788 Bekker, A., Holland, H.D., Wang, P.-L., Rumble, D., Stein, H.J., Hannah, J.L., Coetzee,

789 L.L., Beukes, N.J., 2004. Dating the rise of atmospheric oxygen. Nature 427, 117-120. 
790 Bekker, A., Karhu, J.A., Eriksson, K.A., Kaufman, A.J., 2003a. Chemostratigraphy of

791 Paleoproterozoic carbonate successions of the Wyoming Craton: tectonic forcing of

792 biogeochemical change? Precambrian Research 120, 279-325.

793 Bekker, A., Kasting, J., Anbar, A., 2013. Evolution of the atmosphere and ocean through

794 time. Chemical Geology 362, 1-2.

795 Bekker, A., Kaufman, A.J., Karhu, J.A., Beukes, N.J., Swart, Q.D., Coetzee, L.L.,

796 Eriksson, K.A., 2001. Chemostratigraphy of the Paleoproterozoic Duitschland Formation,

797 South Africa: Implications for coupled climate change and carbon cycling. American

798 Journal of Science 301, 261-285.

799 Bekker, A., Krapež, B., Karhu, J.A., 2002. Preliminary chemostratigraphic data on

800 carbonates from the Paleoproterozoic Turee Creek Supersequence and Wooly Dolomite

801 of Western Australia. 16th International Sedimentologic Congress Abstract Volume, 26-

80227.

803 Bekker, A., Sial, A.N., Karhu, J.A., Ferreira, V.P., Noce, C.M., Kaufman, A.J., Romano,

804 A.W., Pimentel, M.M., 2003b. Chemostratigraphy of carbonates from the Minas

805 Supergroup, Quadrilátero Ferrifero, Brazil: A stratigraphic record of early Proterozoic

806 atmospheric, biogeochemical and climatic change. American Journal of Science 303,

$807 \quad 865-904$.

808 Bergmann, K.D., Grotzinger, J.P., Fischer, W.W., 2013. Biological influences on seafloor

809 carbonate precipitation. Palaios 28, 99-115.

810 Blake, T.S., Barley, M.E., 1992. Tectonic evolution of the late Archaean to early

811 Proterozoic Mount Bruce mega sequence set, Western Australia. Tectonics 11, 1415-

8121425. 
813 Bosak, T., Bush, J., Flynn, M., Liang, B., Ono, S., Petroff, A.P., Sim, M.S., 2010.

814 Formation and stability of oxygen-rich bubbles that shape photosynthetic mats.

815 Geobiology 8, 45-55.

816 Bosak, T., Liang, B., Sim, M.S., Petroff, A.P., 2009. Morphological record of oxygenic

817 photosynthesis in conical stromatolites. Proceedings of the National Academy of

818 Sciences 106, 10939-10943.

819 Brasier, A.T., Martin, A.P., Melezhik, V.A., Prave, A.R., Condon, D.J., Fallick, A.E.,

820 2013. Earth's earliest global glaciation? Carbonate geochemistry and geochronology of

821 the Polisarka Sedimentary Formation, Kola Peninsula, Russia. Precambrian Research

$822 \quad 235,278-294$.

823 Canfield, D.E., 2014. Oxygen: A Four Billion Year History. Princeton University Press,

824 Princeton, New Jersey.

825 Canfield, D.E., Ngombi-Pemba, L., Hammarlund, E.U., Bengtson, S., Chaussidon, M.,

826 Gauthier-Lafaye, F., Meunier, A., Riboulleau, A., Rollion-Bard, C., Rouxel, O., Asael,

827 D., Pierson-Wickmann, A.-C., El Albani, A., 2013. Oxygen dynamics in the aftermath of

828 the Great Oxidation of Earth's atmosphere. Proceedings of the National Academy of

829 Sciences 110, 16736-16741.

830 Farquhar, J., Bao, H., Thiemens, M., 2000. Atmospheric influence of Earth's earliest

831 sulfur cycle. Science 289, 756-758.

832 Flannery, D.T., Walter, M.R., 2012. Archean tufted microbial mats and the Great

833 Oxidation Event: new insights into an ancient problem. Australian Journal of Earth

834 Sciences 59, 1-11. 
835 Fralick, P.W., Poulton, S.W., Canfield, D.E., 2011. Does the Paleoproterozoic Animikie

836 Basin record the sulfidic ocean transition?: COMMENT. Geology 39, e241.

837 Grotzinger, J.P., Knoll, A.H., 1999. Stromatolites in Precambrian carbonates:

838 Evolutionary mileposts or environmental dipsticks? Annual Review of Earth and 839 Planetary Sciences 27, 313-358.

840 Halverson, G.P., Shields-Zhou, G., 2011. Chapter 4 Chemostratigraphy and the

841 Neoproterozoic glaciations. Geological Society, London, Memoirs 36, 51-66.

842 Hannah, J.L., Bekker, A., Stein, H.J., Markey, R.J., Holland, H.D., 2004. Primitive Os

843 and 2316 Ma age for marine shale: implications for Paleoproterozoic glacial events and

844 the rise of atmospheric oxygen. Earth and Planetary Science Letters 225, 43-52.

845 Hoffman, P.F., 2013. The Great Oxidation and a Siderian snowball Earth: MIF-S based

846 correlation of Paleoproterozoic glacial epochs. Chemical Geology 362, 143-156.

847 Hofmann, H.J., Masson, M., 1994. Archean stromatolites from the Abitibi greenstone

848 belt, Quebec, Canada. Geological Society of America Bulletin 106, 424-429.

849 Horwitz, R.C., 1982. Geological history of the Early Proterozoic Paraburdoo Hinge Zone,

850 Western Australia. Precambrian Research 19, 191-200.

851 Hotinski, R.M., Kump, L.R., Arthur, M.A., 2004. The effectiveness of the

852 Paleoproterozoic biological pump: $\mathrm{A} \delta^{13} \mathrm{C}$ gradient from platform carbonates of the

853 Pethei Group (Great Slave Lake Supergroup, NWT). Geological Society of America

854 Bulletin 116, 539-554.

855 Irwin, H., Curtis, C., Coleman, M., 1977. Isotopic evidence for source of diagenetic

856 carbonates formed during burial of organic-rich sediments. Nature 269, 209-213. 
857 Johnston, D.T., Macdonald, F.A., Gill, B.C., Hoffman, P.F., Schrag, D.P., 2012.

858 Uncovering the Neoproterozoic carbon cycle. Nature 483, 320-323.

859 Karhu, J.A., Holland, H.D., 1996. Carbon isotopes and the rise of atmospheric oxygen.

860 Geology 24, 867-870.

861 Kaufman, A.J., Hayes, J.M., Klein, C., 1990. Primary and diagenetic controls of isotopic

862 compositions of iron-formation carbonates. Geochimica et Cosmochimica Acta 54,

$863 \quad 3461-3473$.

864 Kirschvink, J.L., Gaidos, E.J., Bertani, L.E., Beukes, N.J., Gutzmer, J., Maepa, L.N.,

865 Steinberger, R.E., 2000. Paleoproterozoic snowball Earth: Extreme climatic and

866 geochemical global change and its biological consequences. Proceedings of the National

867 Academy of Sciences, U.S.A. 97, 1400-1405.

868 Knoll, A.H., Beukes, N.J., 2009. Introduction: Initial investigations of a Neoarchean shelf

869 margin-basin transition (Transvaal Supergroup, South Africa). Precambrian Research

$870169,1-14$.

871 Knoll, A.H., Wörndle, S., Kah, L.C., 2013. Covariance of microfossil assemblages and

872 microbialite textures across an upper Mesoproterozoic carbonate platform. Palaios 28, $873453-470$.

874 Konhauser, K.O., Lalonde, S.V., Planavsky, N.J., Pecoits, E., Lyons, T.W., Mojzsis, S.J., 875 Rouxel, O.J., Barley, M.E., Rosiere, C., Fralick, P.W., Kump, L.R., Bekker, A., 2011.

876 Aerobic bacterial pyrite oxidation and acid rock drainage during the Great Oxidation

877 Event. Nature 478, 369-373.

878 Konhauser, K.O., Urrutia, M.M., 1999. Bacterial clay authigenesis: a common

879 biogeochemical process. Chemical Geology 161, 399-413. 
880 Krapež, B., 1996. Sequence stratigraphic concepts applied to the identification of basin881 filling rhythms in Precambrian successions. Australian Journal of Earth Sciences 43, $882 \quad 355-380$.

883 Kump, L.R., Junium, C., Arthur, M.A., Brasier, A., Fallick, A., Melezhik, V., Lepland, 884 A., Črne, A.E., Luo, G., 2011. Isotopic evidence for massive oxidation of organic matter 885 following the Great Oxidation Event. Science 334, 1694-1696.

886 Lepot, K., Benzerara, K., Brown, G.E., Phillipot, P., 2008. Microbially influenced

887 formation of 2,724-million-year-old stromatolites. Nature Geoscience 1, 118 - 121.

888 Lepot, K., Benzerara, K., Rividi, N., Cotte, M., Brown Jr, G.E., Philippot, P., 2009.

889 Organic matter heterogeneities in 2.72 Ga stromatolites: Alteration versus preservation

890 by sulfur incorporation. Geochimica et Cosmochimica Acta 73, 6579-6599.

891 Léveillé, R.J., Fyfe, W.S., Longstaffe, F.J., 2000. Geomicrobiology of carbonate-silicate

892 microbialites from Hawaiian basaltic sea caves. Chemical Geology 169, 339-355.

893 Lindsay, J.F., Brasier, M.D., 2002. Did global tectonics drive early biosphere evolution?

894 Carbon isotope record from 2.6 to 1.9 Ga carbonates of Western Australian basins.

895 Precambrian Research 114, 1-34.

896 Lyons, T.W., Reinhard, C.T., Love, G., Xiao, S., 2012. Geobiology of the Proterozoic

897 Eon, in: Knoll, A.H., Canfield, D.E., and Konhauser, K.O. (Ed.), Fundamentals of

898 Geobiology. Blackwell, pp. 371-402.

899 Lyons, T.W., Reinhard, C.T., Planavsky, N.J., 2014. The rise of oxygen in Earth's early

900 ocean and atmosphere. Nature 506, 307-315.

901 Maheshwari, A., Sial, A.N., Gaucher, C., Bossi, J., Bekker, A., Ferreira, V.P., Romano,

902 A.W., 2010. Global nature of the Paleoproterozoic Lomagundi carbon isotope excursion: 
903 A review of occurrences in Brazil, India, and Uruguay. Precambrian Research 182, 274-

904299.

905 Martin, A.P., Condon, D.J., Prave, A.R., Lepland, A., 2013. A review of temporal

906 constraints for the Palaeoproterozoic large, positive carbonate carbon isotope excursion

907 (the Lomagundi-Jatuli Event). Earth-Science Reviews 127, 242-261.

908 Martin, D.M., 1999. Depositional setting and implications of Paleoproterozoic

909 glaciomarine sedimentation in the Hamersley Province, Western Australia. Geological

910 Society of America Bulletin 111, 189-203.

911 Martin, D.M., Li, Z.X., Nemchin, A.A., Powell, C.M., 1998. A pre-2.2 Ga age for giant

912 hematite ores of the Hamersley Province Australia? . Economic Geology 93, 1084-1090.

913 Martin, D.M., Powell, C.M., George, A.D., 2000. Stratigraphic architecture and evolution

914 of the early Paleoproterozoic McGrath Trough, Western Australia. Precambrian Research

$91599,33-64$.

916 Mata, S.A., Harwood, C.L., Corsetti, F.A., Stork, N.J., Eilers, K., Berelson, W.M., Spear,

917 J., 2012. Influences of gas production and filament orientation on stromatolite

918 microfabric. Palaios 27, 206-219.

919 Mazumder, R., Van Kranendonk, M.J., Altermann, W., 2015. A marine to fluvial

920 transition in the Paleoproterozoic Koolbye Formation, Turee Creek Group, Western

921 Australia. Precambrian Research 258, 161-170.

922 McLoughlin, N.J., Melezhik, V.A., Brasier, A.T., Medvedev, P.V., 2013.

923 Palaeoproterozoic stromatolites from the Lomagundi-Jatuli interval of the Fennoscandian

924 Shield., in: A. Prave, A.E.F., V.A. Melezhik, A. Lepland, E.J. Hanski, \& H. Strauss (Ed.),

925 Reading the archive of Earth's oxygenation: Global events and the Fennoscandian Arctic 
926 Russia - Drilling Early Earth Project (FAR-DEEP) (Frontiers in Earth Sciences, 3).

927 Springer, Heidelberg, pp. 1298-1351.

928 Medvedev, P., Bekker, A., Karhu, J.A., Kortelainen, N., 2005. Testing the

929 biostratigraphic potential of early Paleoproterozoic microdigitate stromatolites. Revista

930 Española de Micropaleontologia 37, 41-56.

931 Melezhik, V.A., Fallick, A.E., 2010. On the Lomagundi-Jatuli carbon isotopic event: The

932 evidence from the Kalix Greenstone Belt, Sweden. Precambrian Research 179, 165-190.

933 Mohanty, S.P., Barik, A., Sarangi, S., Sarkar, A., 2015. Carbon and oxygen isotope

934 systematics of a Paleoproterozoic cap-carbonate sequence from the Sausar Group,

935 Central India. Palaeogeography, Palaeoclimatology, Palaeoecology 417, 195-209.

936 Müller, S.G., Krapež, B., Barley, M.E., Fletcher, I.R., 2005. Giant iron-ore deposits of

937 the Hamersley province related to the breakup of Paleoproterozoic Australia: New

938 insights from in situ SHRIMP dating of baddeleyite from mafic intrusions. Geology 33,

$939 \quad 577-580$.

940 Partin, C.A., Lalonde, S.V., Planavsky, N.J., Bekker, A., Rouxel, O.J., Lyons, T.W.,

941 Konhauser, K.O., 2013. Uranium in iron formations and the rise of atmospheric oxygen.

942 Chemical Geology 362, 82-90.

943 Planavsky, N.J., Asael, D., Hofmann, A., Reinhard, C.T., Lalonde, S.V., Knudsen, A.,

944 Wang, X., Ossa, F.O., Pecoits, E., Smith, A.J.B., Beukes, N.J., Bekker, A., Johnson,

945 T.M., Konhauser, K.O., Lyons, T.W., Rouxel, O.J., 2014. Evidence for oxygenic

946 photosynthesis half a billion years before the Great Oxidation Event. Nature Geoscience

$947 \quad 7,283-286$. 
948 Planavsky, N.J., Bekker, A., Hofmann, A., Owens, J.D., Lyons, T.W., 2012. Sulfur

949 record of rising and falling marine oxygen and sulfate levels during the Lomagundi event.

950 Proceedings of the National Academy of Sciences 109, 18300-18305.

951 Powell, C.M., Horwitz, R.C., 1994. Late Archaean and early Proterozoic tectonics and

952 basin formation of the Hamersley Ranges, Twelfth Australian Geological Convention,

953 Perth, Geological Society of Australia (WA Division), Excursion Guidebook, 4, p. 53.

954 Pufahl, P.K., Hiatt, E.E., 2012. Oxygenation of the Earth's ocean-atmosphere system: a

955 review of physical and chemical sedimentological responses. Marine and Petroleum

956 Geology 32, 1-20.

957 Pufahl, P.K., Hiatt, E.E., Kyser, T.K., 2010. Does the Paleoproterozoic Animikie Basin

958 record the sulfidic ocean transition? Geology 38, 659-662.

959 Pufahl, P.K., Hiatt, E.E., Kyser, T.K., 2011. Does the Paleoproterozoic Animikie Basin

960 record the sulfidic ocean transition? REPLY. Geology 39, e242-e243.

961 Rasmussen, B., Bekker, A., Fletcher, I.R., 2013. Correlation of Paleoproterozoic

962 glaciations based on $\mathrm{U}-\mathrm{Pb}$ zircon ages for tuff beds in the Transvaal and Huronian

963 Supergroups. Earth and Planetary Science Letters 382, 173-180.

964 Reinhard, C.T., Planavsky, N.J., Robbins, L.J., Partin, C.A., Gill, B.C., Lalonde, S.V.,

965 Bekker, A., Konhauser, K.O., Lyons, T.W., 2013. Proterozoic ocean redox and

966 biogeochemical stasis. Proceedings of the National Academy of Sciences 110, 5357-

9675362.

968 Riding, R., Fralick, P., Liang, L., 2014. Identification of an Archean marine oxygen oasis.

969 Precambrian Research 251, 232-237. 
970 Scott, C., Wing, B.A., Bekker, A., Planavsky, N.J., Medvedev, P., Bates, S.M., Yun, M.,

971 Lyons, T.W., 2014. Pyrite multiple-sulfur isotope evidence for rapid expansion and

972 contraction of the early Paleoproterozoic seawater sulfate reservoir. Earth and Planetary

973 Science Letters 389, 95-104.

974 Sumner, D.Y., 1997. Late Archean calcite-microbe interactions: Two morphologically

975 distinct microbial communities that affected calcite nucleation differently. Palaios 12,

$976 \quad 302-318$.

977 Swanner, E.D., Planavsky, N.J., Lalonde, S.V., Robbins, L.J., Bekker, A., Rouxel, O.J.,

978 Saito, M.A., Kappler, A., Mojzsis, S.J., Konhauser, K.O., 2014. Cobalt and marine redox

979 evolution. Earth and Planetary Science Letters 390, 253-263.

980 Takehara, M., Komure, M., Kiyokawa, S., Horie, K., Yokohama, K., 2010. Detrital

981 zircon SHRIMP U-Pb age of the 2.3Ga diamictites of the Meteorite Bore Member in the

982 South Pilbara, Western Australia., in: Tyler, I.M., Knox-Robinson, C.M. (Eds.), Fifth

983 International Archean Symposium Abstracts: Geological Survey of Western Australia,

984 Record 2010/18, pp. 223-222.

985 Thorne, A.M., 1990. Ashburton Basin, in Geology and Mineral Resources of Western

986 Australia: Geological Survey of Western Australia, Memoir 3, 210-219.

987 Thorne, A.M., Seymour, D.B., 1991. Geology of the Ashburton Basin Western Australia:

988 Geological Survey of Western Australia, Bulletin 139.

989 Thorne, A.M., Tyler, I.M., 1996. Roy Hill, Western Australia Sheet 50-12: Geological

990 Survey of Western Australia, 1:250 000 map series.

991 Thorne, A.M., Tyler, I.M., Blight, D.F., 1995. Rocklea, Western Australia: Geological

992 Survey of Western Australia, 1:100 000 geological series. 
993 Trendall, A.F., 1969. Three great basins of Precambrian banded iron formation

994 deposition: A systematic comparison. Geological Society of America Bulletin 79, 1527-

9951544.

996 Trendall, A.F., 1976. Striated and faceted boulders from the Turee Creek Formation -

997 Evidence for a possible Huronian glaciation on the Australian continent, Geological

998 Survey of Western Australia Annual Report 1975, pp. 88-92.

999 Trendall, A.F., 1979. A revision of the Mount Bruce Supergroup. Geological Survey of

1000 Western Australia Annual Report 1978, 63-71.

1001 Trendall, A.F., 1981. The Lower Proterozoic Meteorite Bore Member, Hamersley Basin,

1002 Western Australia, in: Hambrey, M.J., Harland, W.B. (Eds.), Earth's Pre-Pleistocene

1003 glacial record. Cambridge University Press, Cambridge, pp. 555-557.

1004 Trendall, A.F., 1990. Hamersley Basin, in Geology and Mineral Resources of Western

1005 Australia. Geological Survey of Western Australia, Memoir 3, 163-190.

1006 Trendall, A.F., Blockley, J.G., 1970. The iron formations of the Precambrian Hamersley

1007 Group, Western Australia with special reference to the crocidolite. Geological Survey of

1008 Western Australia, Bulletin 119, 1-366.

1009 Trendall, A.F., Trendall, A.F., Morris, R.C., 1983. Chapter 3 The Hamersley Basin,

1010 Developments in Precambrian Geology. Elsevier, pp. 69-129.

1011 Tyler, I.M., Thorne, A.M., 1990. The northern margin of the Capricorn Orogen, Western

1012 Australia — an example of an Early Proterozoic collision zone. Journal of Structural

1013 Geology 12, 685-701.

1014 Van Kranendonk, M., 2010. Three and a half billion years of life on Earth: A transect

1015 back in time. Geological Survey of Western Australia Record 2010/21. 
1016 Van Kranendonk, M.J., Altermann, W., Beard, B.L., Hoffman, P.F., Johnson, C.J., 1017 Kasting, J.F., Melezhik, V.A., Nutman, A.P., Papineau, D., Pirajno, F., 2012. A

1018 chronostratigraphic division of the Precambrian: possibilities and challenges, in:

1019 Gradstein, F.M., Ogg, J.G., Schmitz, M.D., Ogg, G.J. (Eds.), The Geologic Time Scale 1020 2012. Elsevier, Boston, USA, pp. 299-392.

1021 Van Kranendonk, M.J., Mazumder, R., 2015. Two Paleoproterozoic glacio-eustatic 1022 cycles in the Turee Creek Group, Western Australia. Geological Society of America 1023 Bulletin 127, 596-607.

1024 Van Kranendonk, M.J., Mazumder, R., Yamaguchi, K.E., Yamada, K., Ikehara, M., 1025 2015. Sedimentology of the Paleoproterozoic Kungarra Formation, Turee Creek Group, 1026 Western Australia: A conformable record of the transition from early to modern Earth. 1027 Precambrian Research 256, 314-343.

1028 Williford, K.H., Van Kranendonk, M.J., Ushikubo, T., Kozdon, R., Valley, J.W., 2011.

1029 Constraining atmospheric oxygen and seawater sulfate concentrations during

1030 Paleoproterozoic glaciation: In situ sulfur three-isotope microanalysis of pyrite from the

1031 Turee Creek Group, Western Australia. Geochimica et Cosmochimica Acta 75, 568610325705.

1033

1034 


\section{Figure captions}

1036 Figure 1. Geographic, stratigraphic, and geological location of the studied sections.

1037 Upper left: Location of study area in Australia (star). Upper right: stratigraphic context

1038 for the Turee Creek Group; stars indicate stratigraphic horizons of studied sections.

1039 Bottom: Geological map of the Hardey Syncline from Martin et al. (2000); numbered

1040 circles indicate studied localities.

1041

1042 Figure 2. Litho- and chemostratigraphy of the Kungarra Formation section at Horseshoe

1043 Creek (composite section of stratigraphic columns HC1, HC2, and HC3). The

1044 stratigraphic interval between $33.9 \mathrm{~m}$ and $34.4 \mathrm{~m}$ has been enlarged to show the

1045 succession of stromatolitic textures (interpreted to be of microbial origin). Inset images

1046 are photomicrographs (plane polarized light) of the Kungarra carbonates; sample HC2

$104712.5 \mathrm{~A}$ is from $13.8 \mathrm{~m}$ and $\mathrm{HC} 340.2$ is from $40.2 \mathrm{~m}$. Dots in inset images indicate

1048 microsampling locations and their carbon isotope values.

1049

1050 Figure 3. Kungarra Formation carbonates at Horseshoe Creek. A) Pinkish-white micritic

1051 limestone interbedded with reddish-brown fine-grained sandstone forming starved

1052 ripples, Australian dollar for scale (25 mm diameter). B) Close up of stromatolites from

1053 roughly $34.2 \mathrm{~m}$ in stratigraphic height, Australian dollar for scale. C) Petrographic view

1054 of the domal stromatolite layer (Sample HC3 34.3,34.3m in stratigraphic height),

1055 showing overgrowths of calcite on micritic carbonates stained by iron oxides (note scale

1056 bar).

1057 
1058 Figure 4. Elemental map of Kungarra Formation limestone (sample HC3 16.25 from

$105916.25 \mathrm{~m}$ in stratigraphic height); top images are the entire sample, and the bottom images

1060 are close up views of the boxed area. On the left are SEM images, on the right are false

1061 color representations of the elemental maps, and the middle images are a composite

1062 image of the SEM images and elemental maps. Note that the calcium (calcite) only

1063 manifests in rare lenses with abundant detrital minerals, suggesting that it is not primary

1064 carbonate but rather diagenetic.

1065

1066 Figure 5. Lithologies of the Kazput Formation in Hardey Syncline section K1. A)

1067 Overview of stratigraphy, section K1 begins in the thin-bedded limestones in the

1068 foreground, the base of the cliff is at $53 \mathrm{~m}$ elevation in the stratigraphic column (Fig. 6),

1069 and the measured section continues up the gully on the left. B) Close-up of thin-bedded

1070 limestones at the base of the K1 section, hammer for scale. C) Cross-stratified

1071 grainstones with abundant bed-parallel silicification at meter 108 in the K1 section,

1072 Sharpie tip for scale.

1073

1074 Figure 6. Litho- and chemostratigraphy of the Kazput Formation at section K1.

1075

1076 Figure 7. Lithologies of the Kazput Formation in Hardey Syncline section K2. A)

1077 Overview of stratigraphy, showing where individual subsections were measured. B) Fine

1078 grained, parallel-laminated facies in section K2A, Australian dollar for scale ( $25 \mathrm{~mm}$

1079 diameter). C) Section K2B; silty to (fine) sandy carbonates with small-scale ripples in the

1080 lower half of the photo and mm-scale laminations in the upper half. Blue ruler at the 
1081 bottom of the photo is $10.5 \mathrm{~cm}$ long. D) Interbedded sandy carbonates and fine-grained 1082 carbonates with wavy to stromatolitic laminae (section K2B); rock hammer for scale.

1084 Figure 8. Litho- and chemostratigraphy of the Kazput Formation at sections K2A and 1085 K2A2. Note that K2A2 sits stratigraphically above the K2A section.

1087 Figure 9. Litho- and chemostratigraphy of Kazput Formation at sections K2B and K2C.

1088 Expanded section in upper right highlights geochemical results from stromatolite 1089 microsampling.

1091 Figure 10. Kazput stromatolites. A) Large domal stromatolites forming over relict 1092 topography at $47 \mathrm{~m}$ stratigraphic height (in section K2C). B) Thin stromatolite layer 1093 within fine-grained micritic limestones; note the eroded base on which the stromatolite 1094 accreted. C) Alternating layers of siliciclastic lamina-rich (resistant) and carbonate-rich 1095 (recessive) layers within the larger stromatolites; note the weathering difference between 1096 units. D) Top layers of domal stromatolites from K2C (47 m), note the alternating layers 1097 of siliciclastic lamina-rich and carbonate-rich layers. The stromatolites on the top layer 1098 formed much larger $(>5 \mathrm{~cm})$, more cement-rich structures than earlier layers. E)

1099 Synsedimentary neptunian dyke through stromatolite layers, dark patches are shadows 1100 from vegetation on the outcrop. F) Domal stromatolites growing into microdigitate 1101 stromatolites within cement-rich intervals of the large domal stromatolites in K2C. 1102 
1103 Figure 11. Petrographic textures of Kazput stromatolites (all plane polarized light). A)

1104 Alternating siliciclastic lamina-rich and discontinuous carbonate-rich layers of large

1105 domal stromatolites from section K2C (47 m, sample K2C 5.5B2); B) Unusually

1106 continuous carbonate-rich layers in section K2C (65.7 m, sample K2C 31.8m); C)

1107 Microstructure of a transported and rolled up stromatolite, showing the local preservation

1108 of fine banding in lenticular carbonate precipitates highlighted by arrows (63.4 m, sample

1109 K2C 28.6); D) Detail of a siliciclastic-rich lamina in a small stromatolite containing

1110 quartz, pyrite, and clay minerals, with carbonate-rich areas above and below (Sample

1111 K2C 28.5); E) Close up of Fig. 11C highlighting the faint banding within the carbonate

1112 fabric of the deformed stromatolite (63.4 m sample K2C 28.6).

1113

1114 Figure 12. Elemental map of Kazput Formation stromatolitic carbonates (sample KAZS1,

$111547 \mathrm{~m}$ height in section $\mathrm{K} 2 \mathrm{C}$ ); top row is an image of the entire sample, and the middle

1116 and bottom rows are close up views of boxes 1 and 2 respectively. Left column are SEM

1117 images, right column images are false color representations of the elemental maps, and

1118 the middle illustrations are composite images of the elemental and SEM maps. Note,

1119 unlike the Kungarra Fm. (Fig. 4), calcium (calcite) is the dominant mineral with quartz

1120 and aluminosilicates occurring with high relative abundance in stromatolitic laminae.

1121 Small iron oxide grains (blue in false color maps) occur throughout the Kazput section

1122 but are concentrated in silicate-rich laminae (orange in false color maps). There are also

1123 organic carbon inclusions throughout the section (see second row); they appear as black

1124 spots in the composite figure and are highlighted in red on the carbon (C) elemental map.

1125 


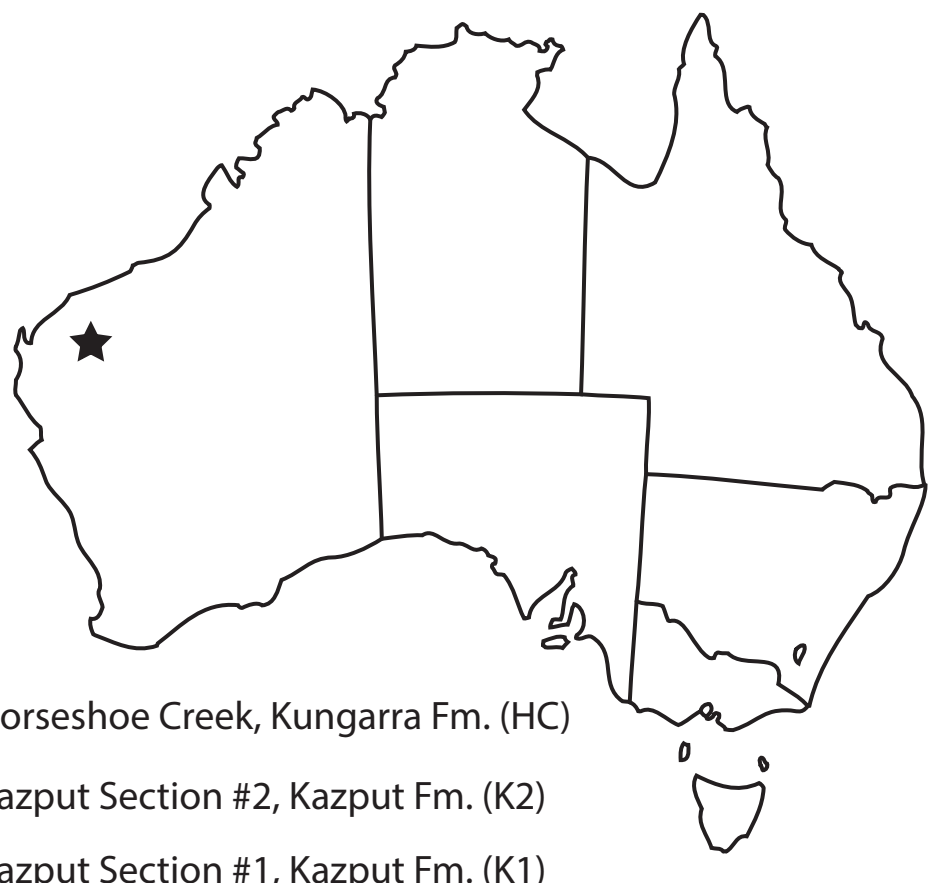

\begin{tabular}{|c|c|}
\hline \multirow{3}{*}{$\begin{array}{l}\text { Wyloo } \\
\text { Group }\end{array}$} & Mount McGrath Formation \\
\hline & $\begin{array}{l}\text { Cheela Springs Basalt } \\
\qquad(2209 \pm 15 \mathrm{Ma})\end{array}$ \\
\hline & Beasley River Quartzite \\
\hline \multirow{3}{*}{$\begin{array}{l}\text { Turee } \\
\text { Creek } \\
\text { Group }\end{array}$} & Kazput Formation \\
\hline & Koolbye Formation \\
\hline & 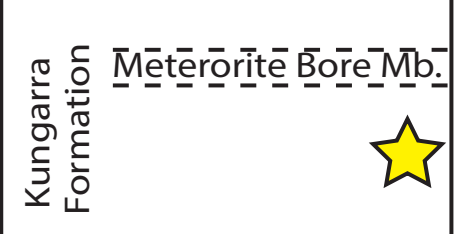 \\
\hline \multirow{3}{*}{$\begin{array}{c}\text { Hamersley } \\
\text { Group }\end{array}$} & Boolgeda Iron Formation \\
\hline & $\begin{array}{c}\text { Woongarra Rhyolite } \\
(2449 \pm 3 \mathrm{Ma})\end{array}$ \\
\hline & Weeli Wolli Formation \\
\hline
\end{tabular}

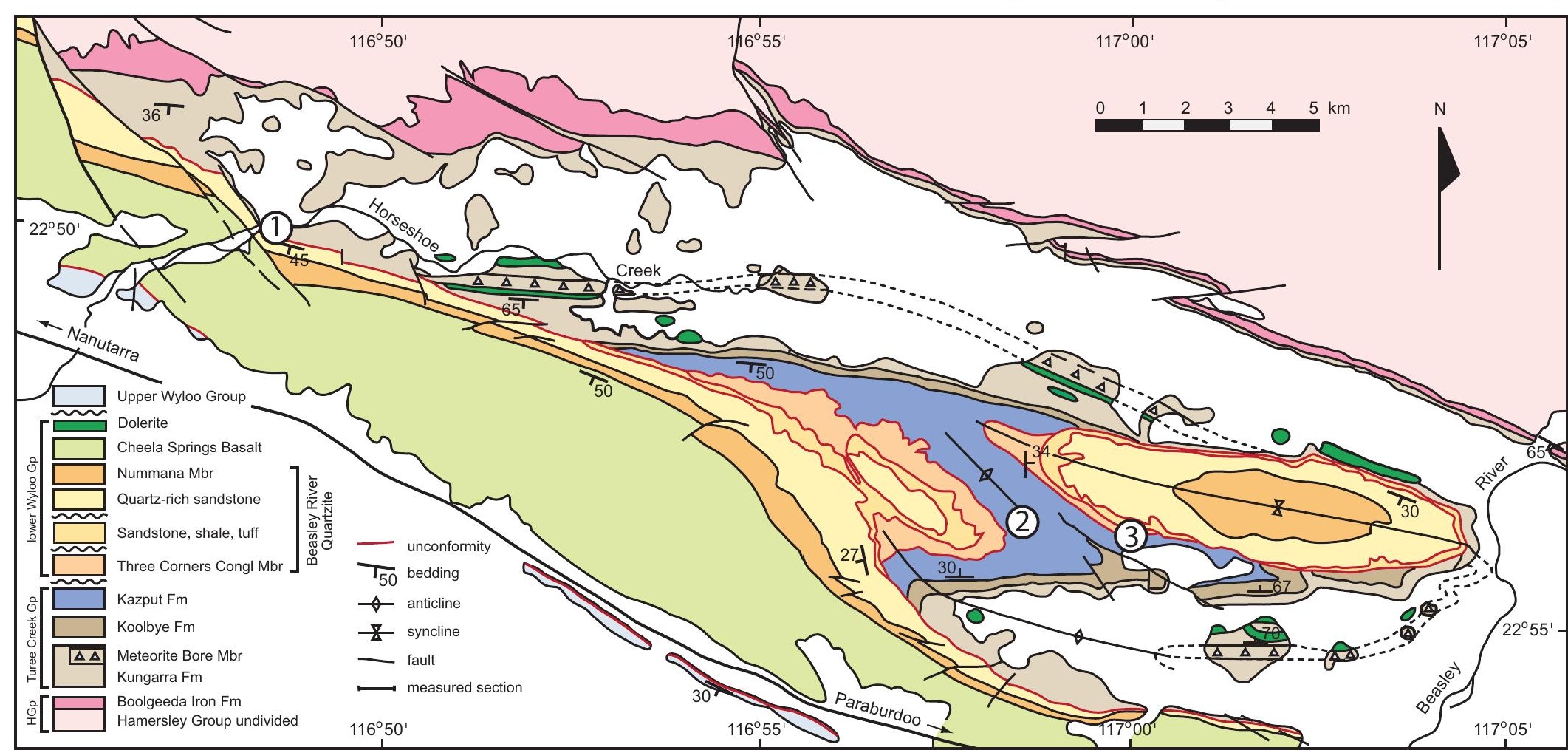


Figure 2

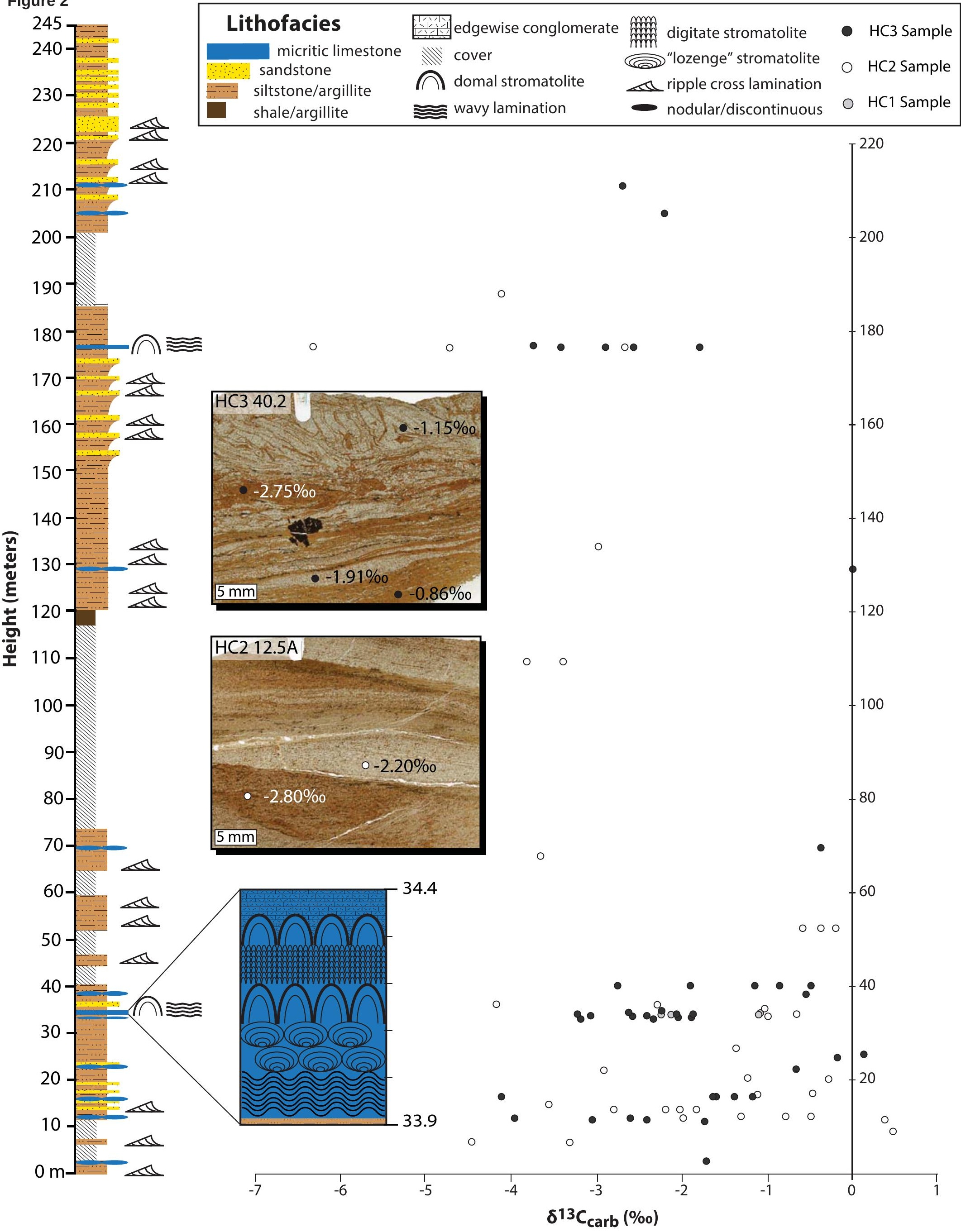


Click here to download high resolution image
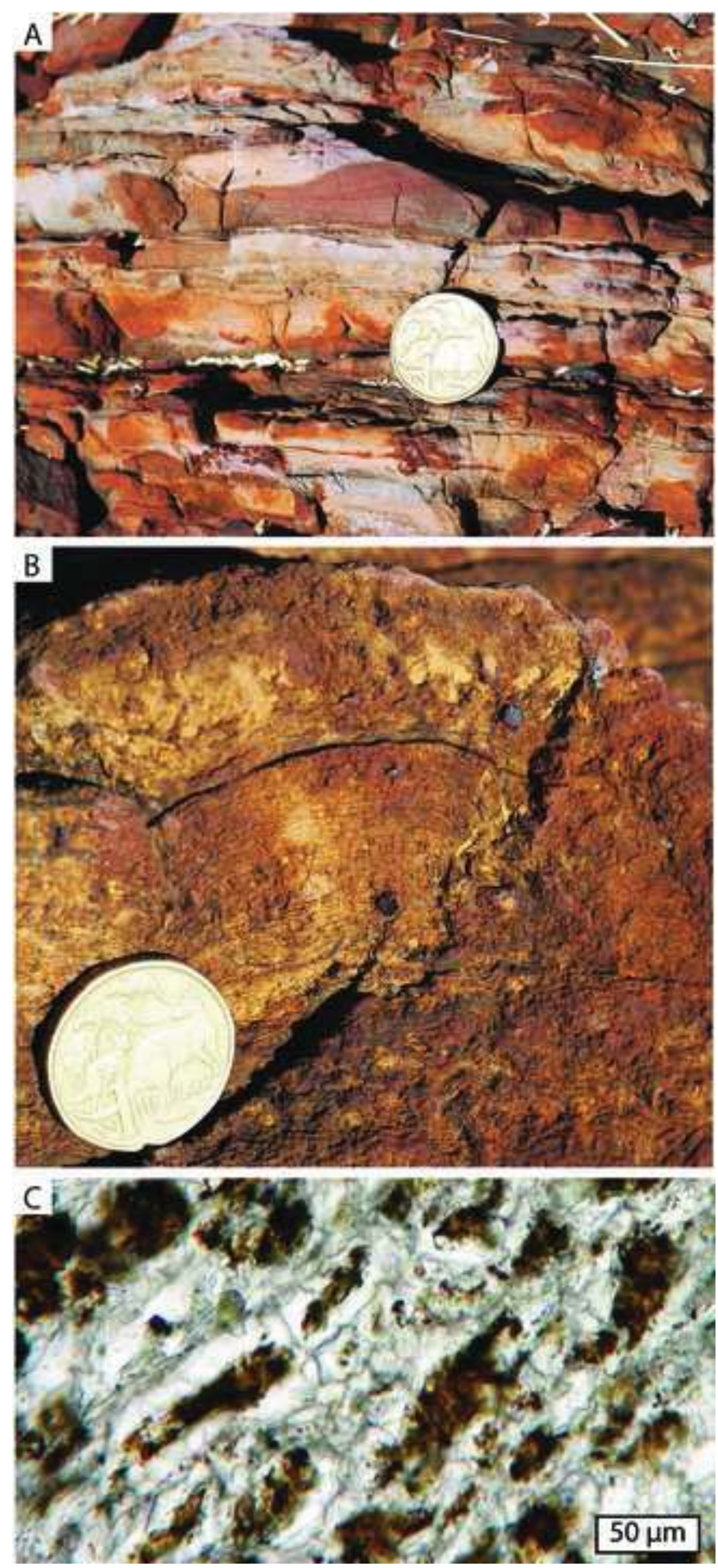
Figure 4

\section{HC3 16.25m - Kungarra carbonate}

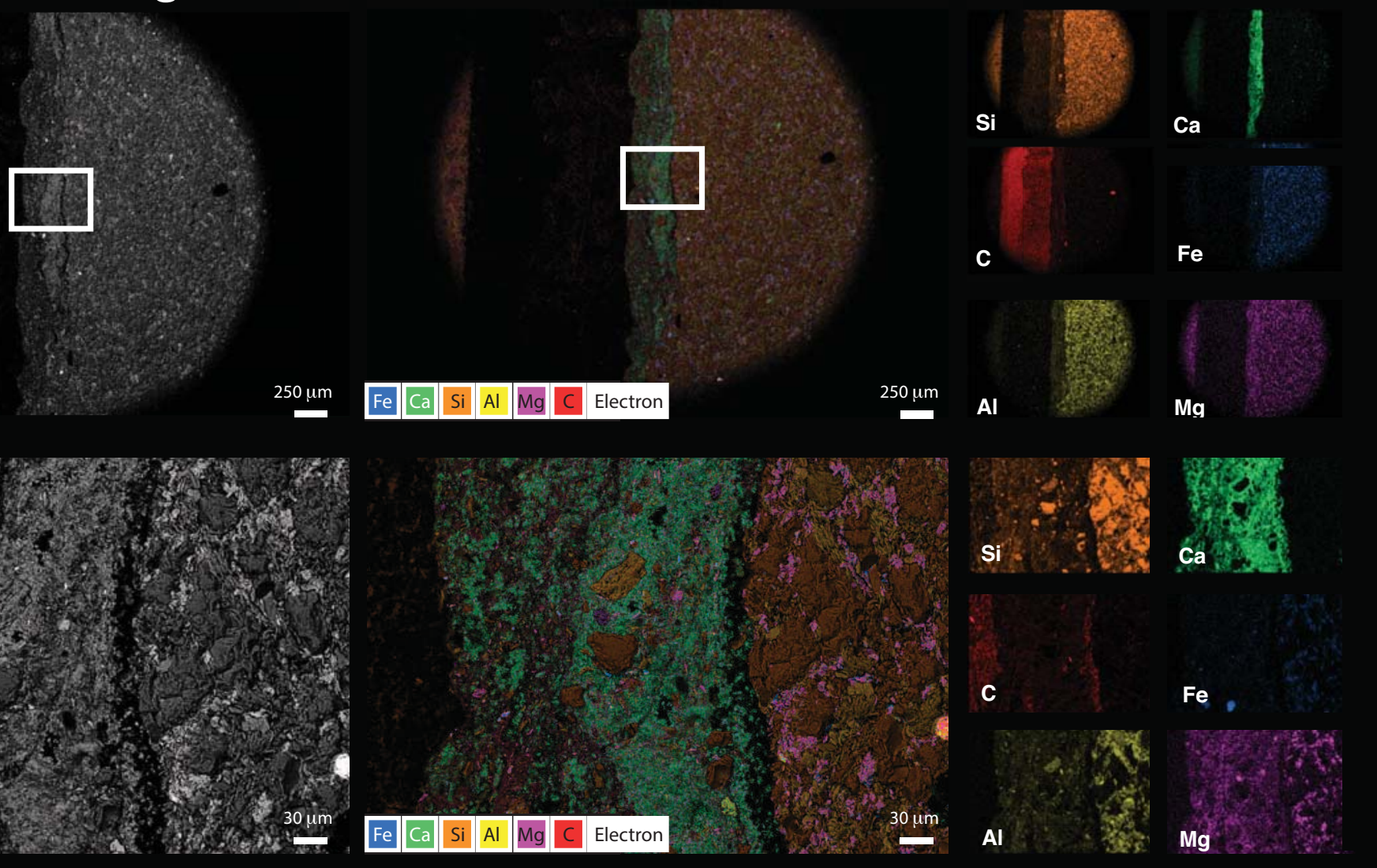


Click here to download high resolution image
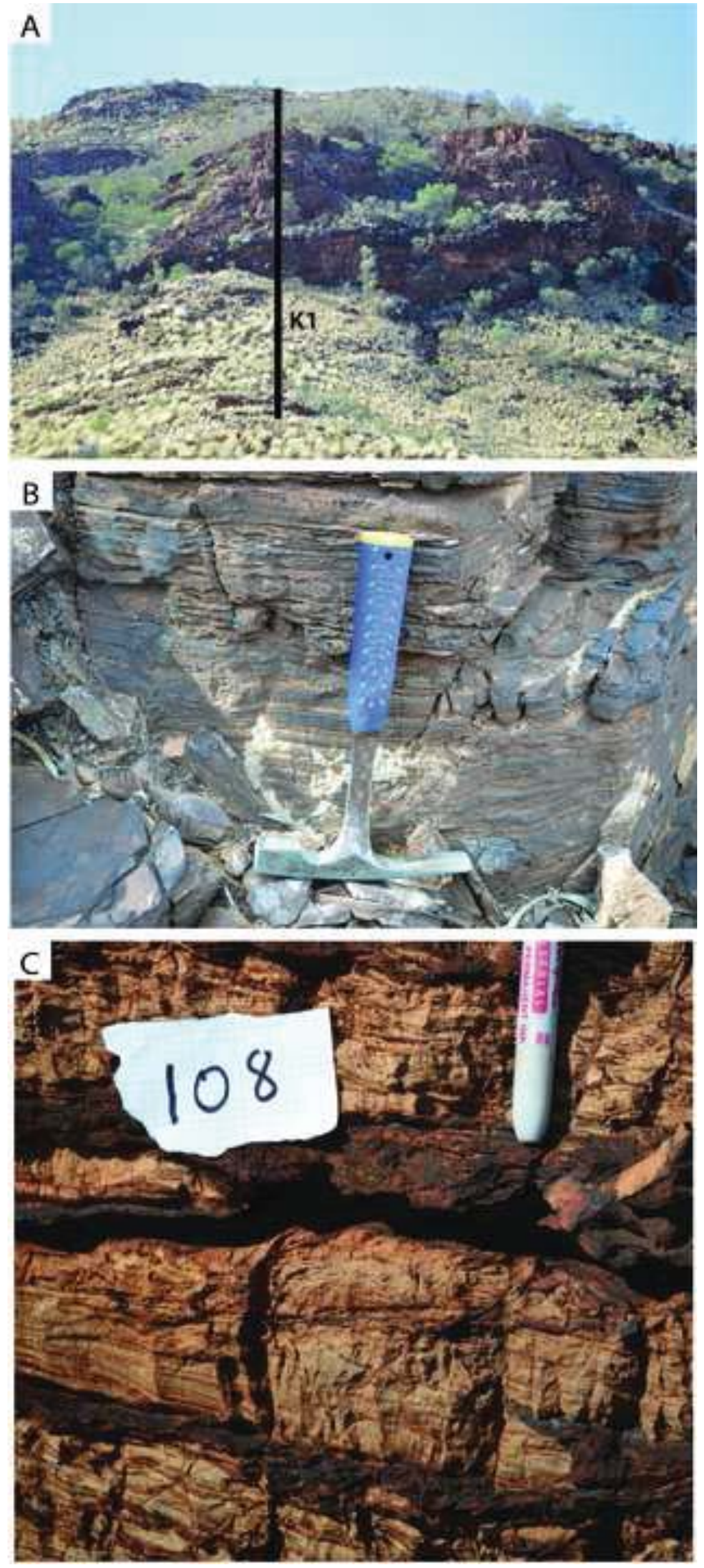

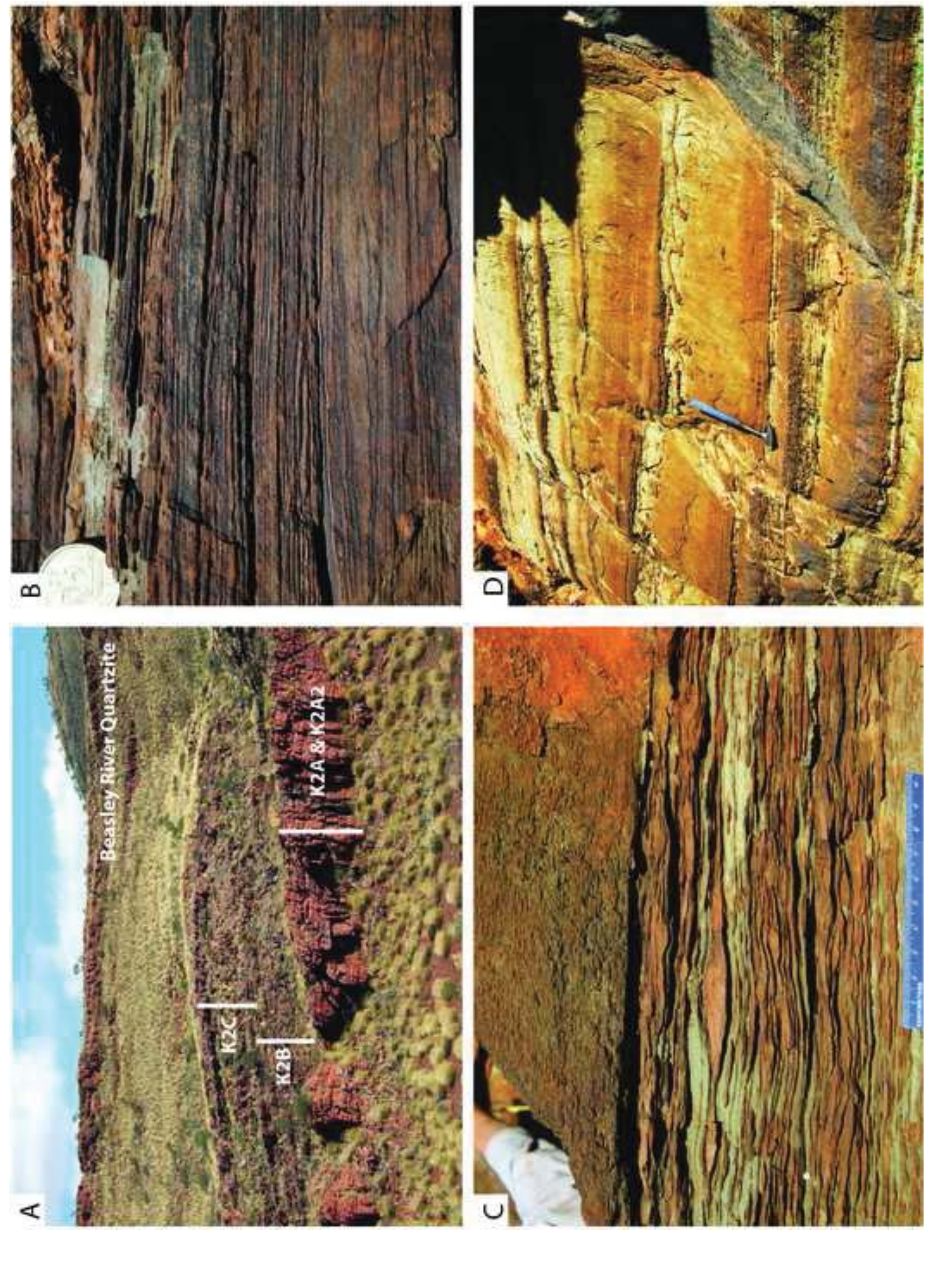


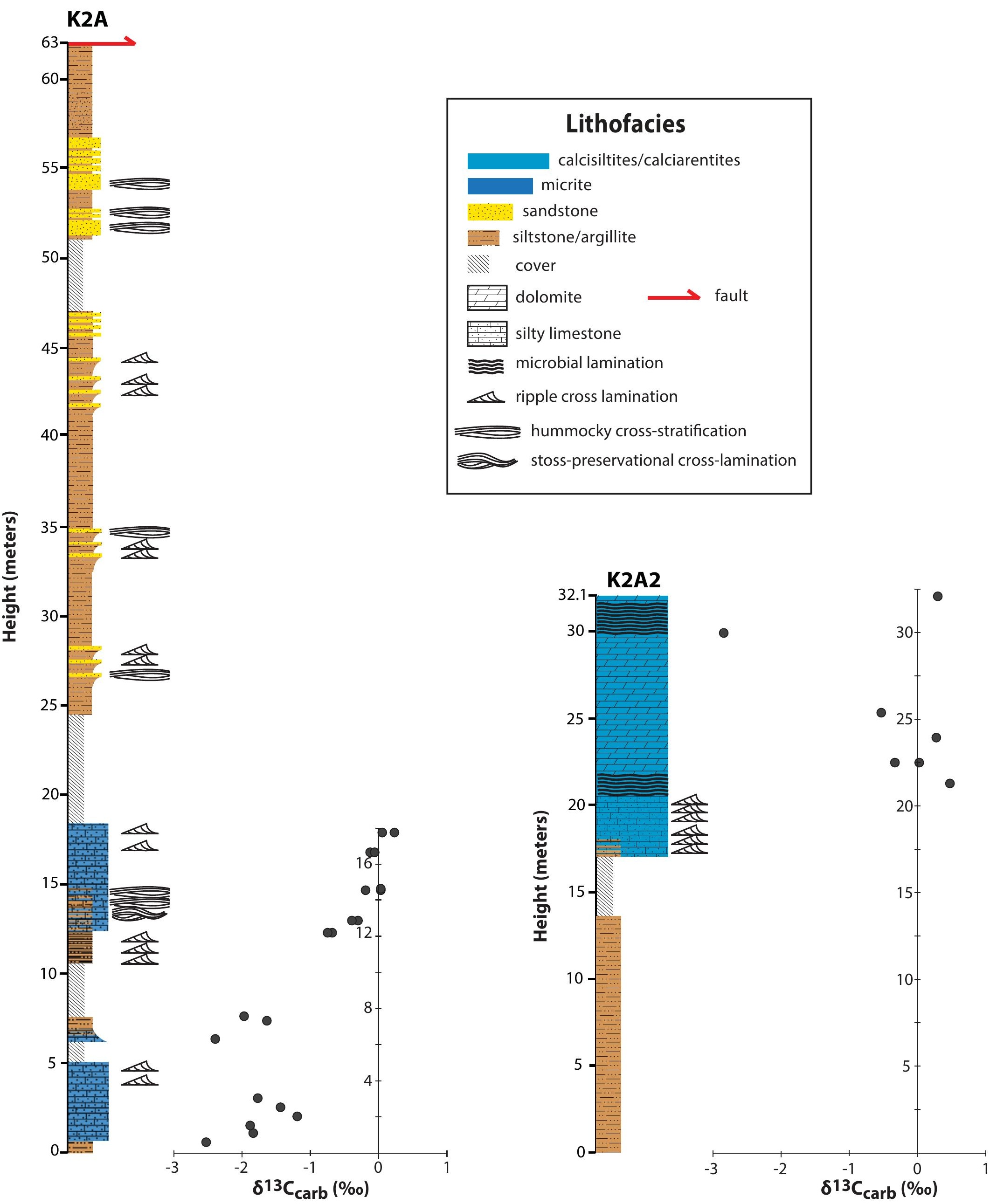




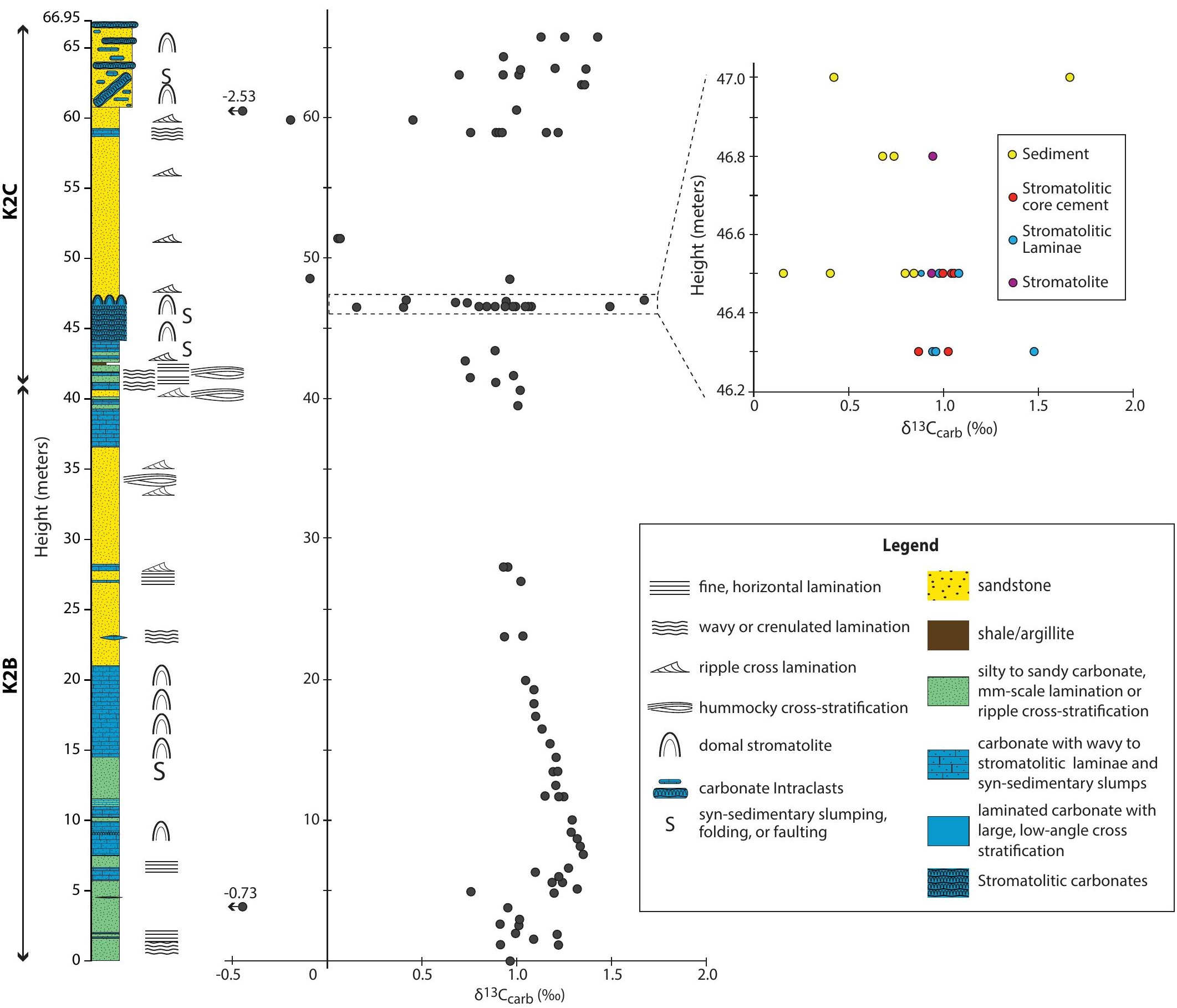



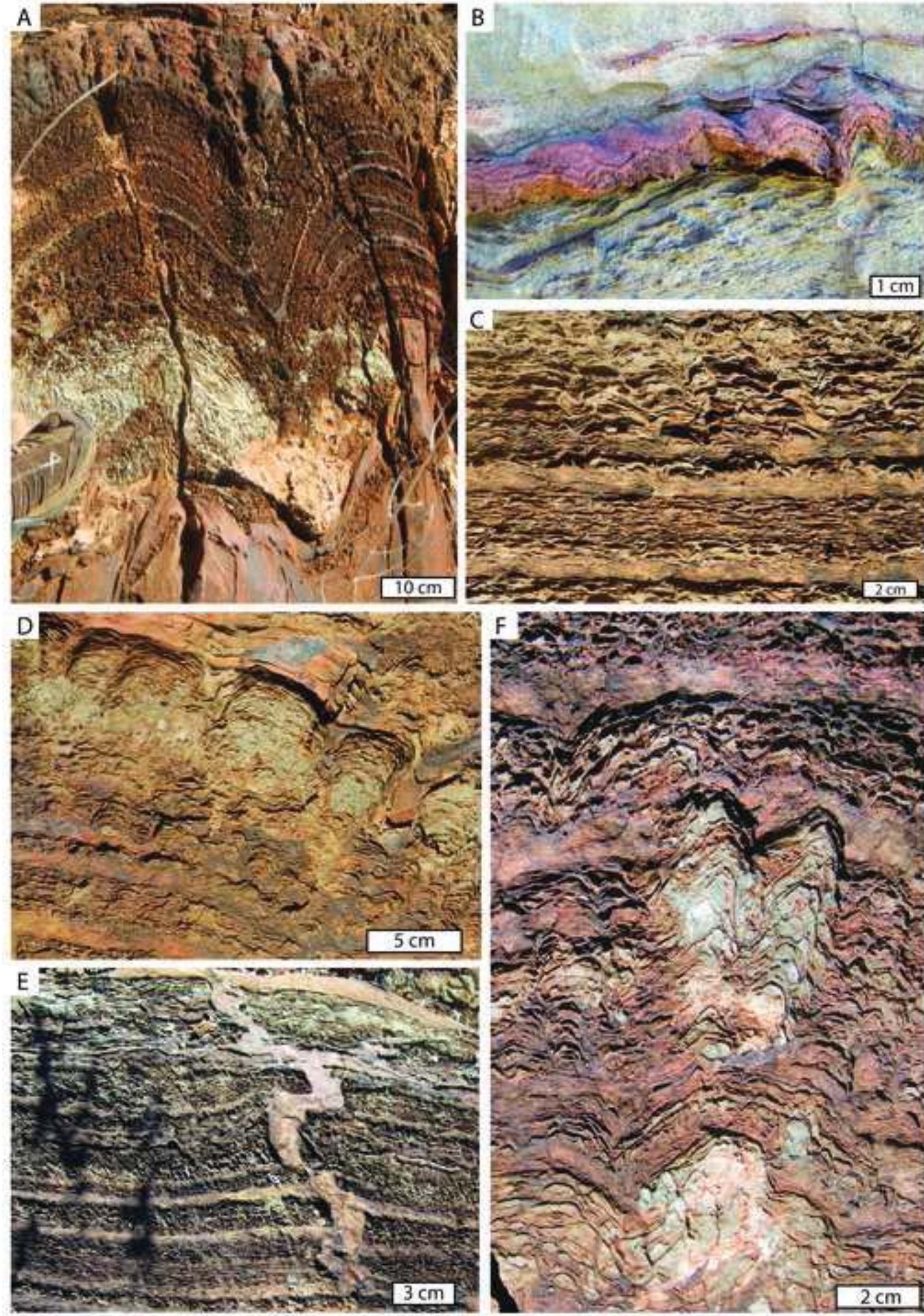

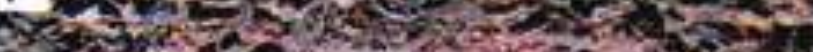

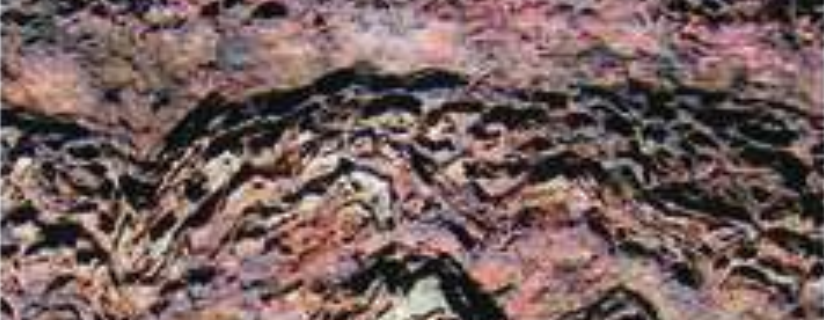

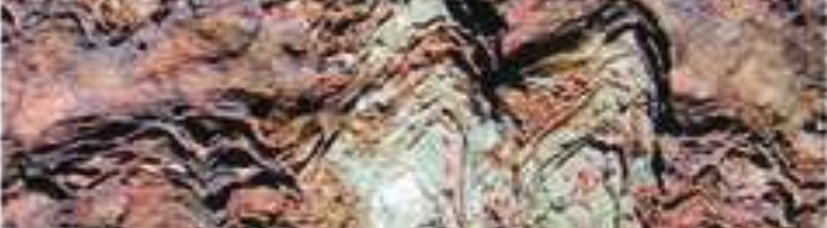

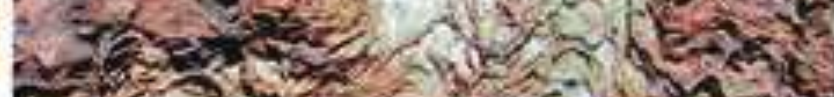

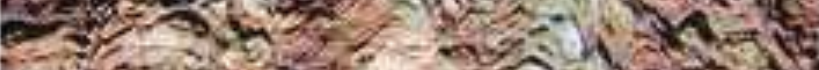

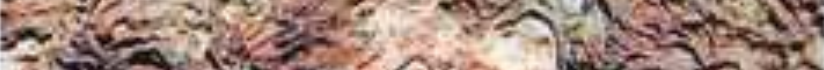

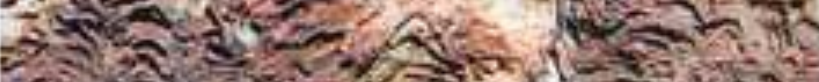

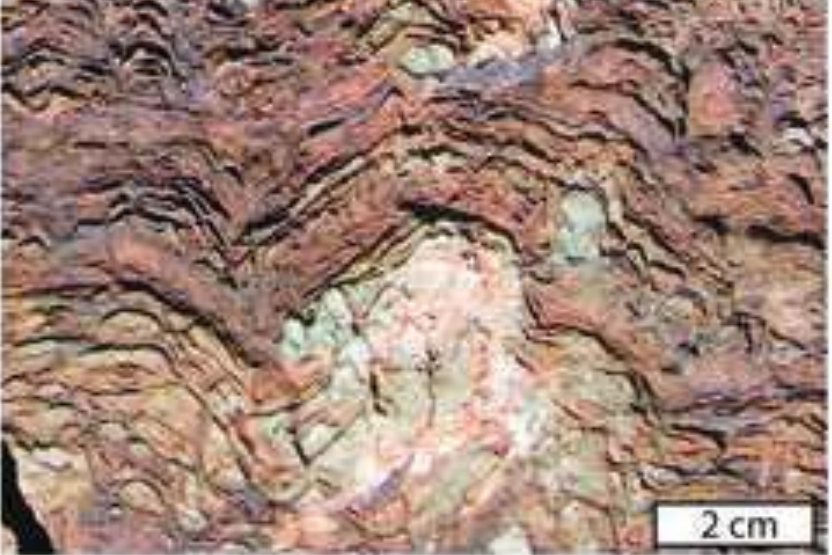




\section{Figure 11}

Click here to download high resolution image

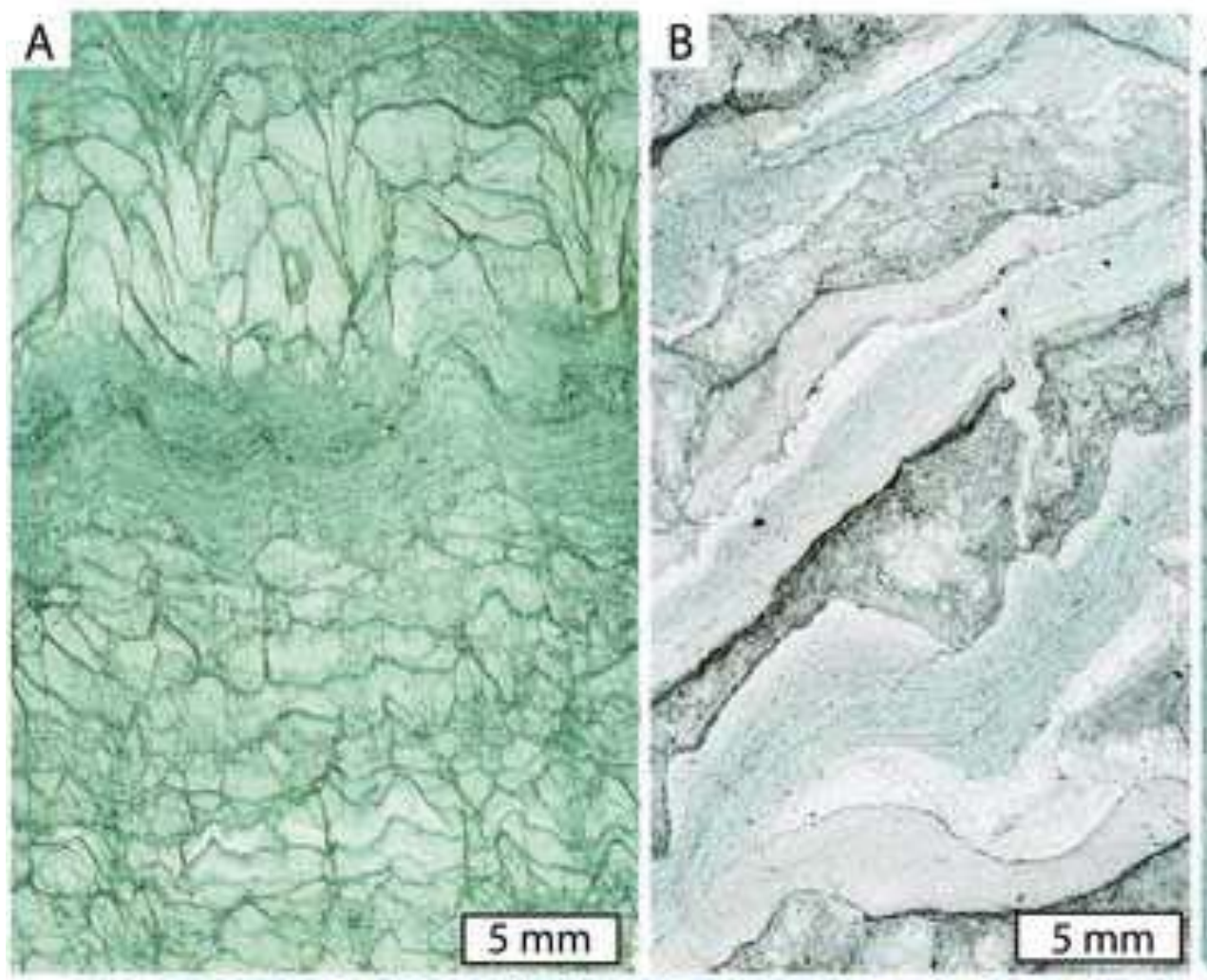

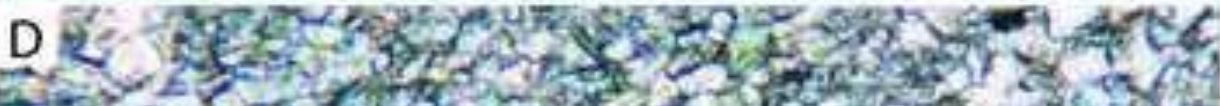
Fen

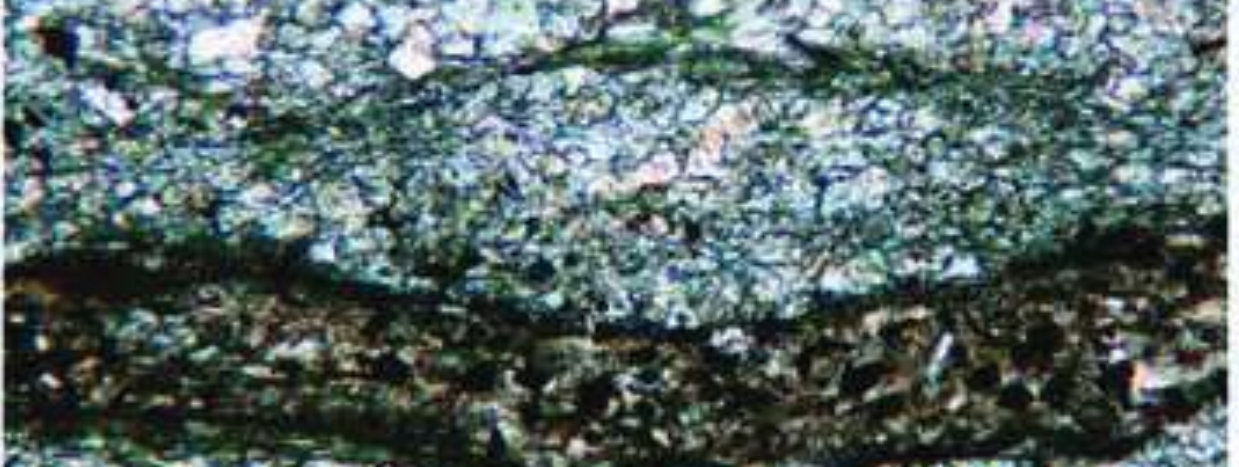

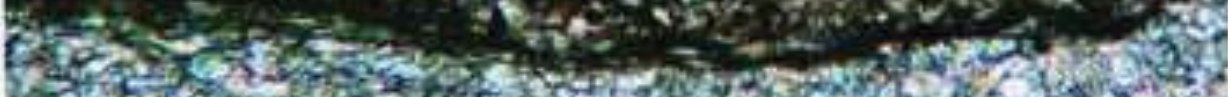

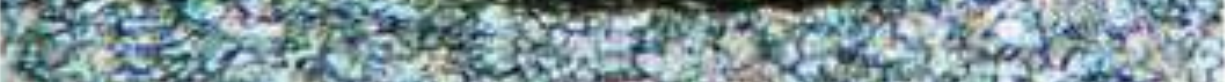
If

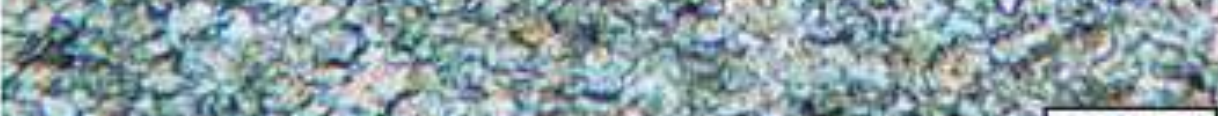
3.
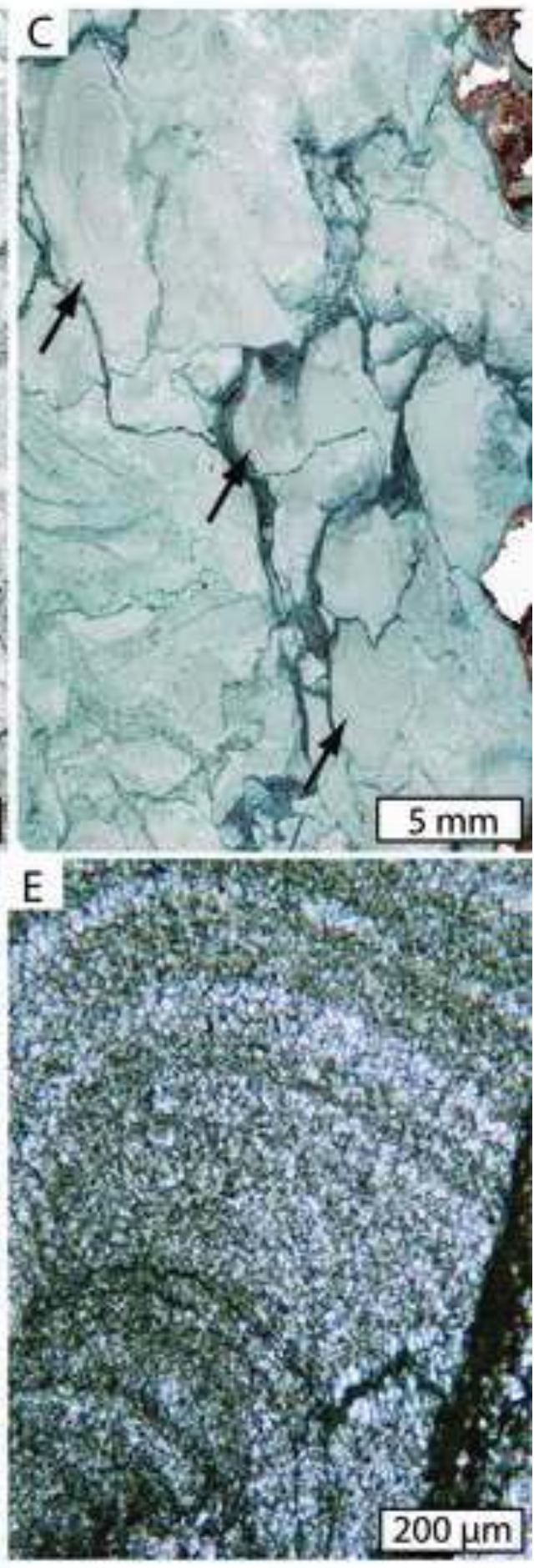


\section{KAZS1 - Kazput carbonate}
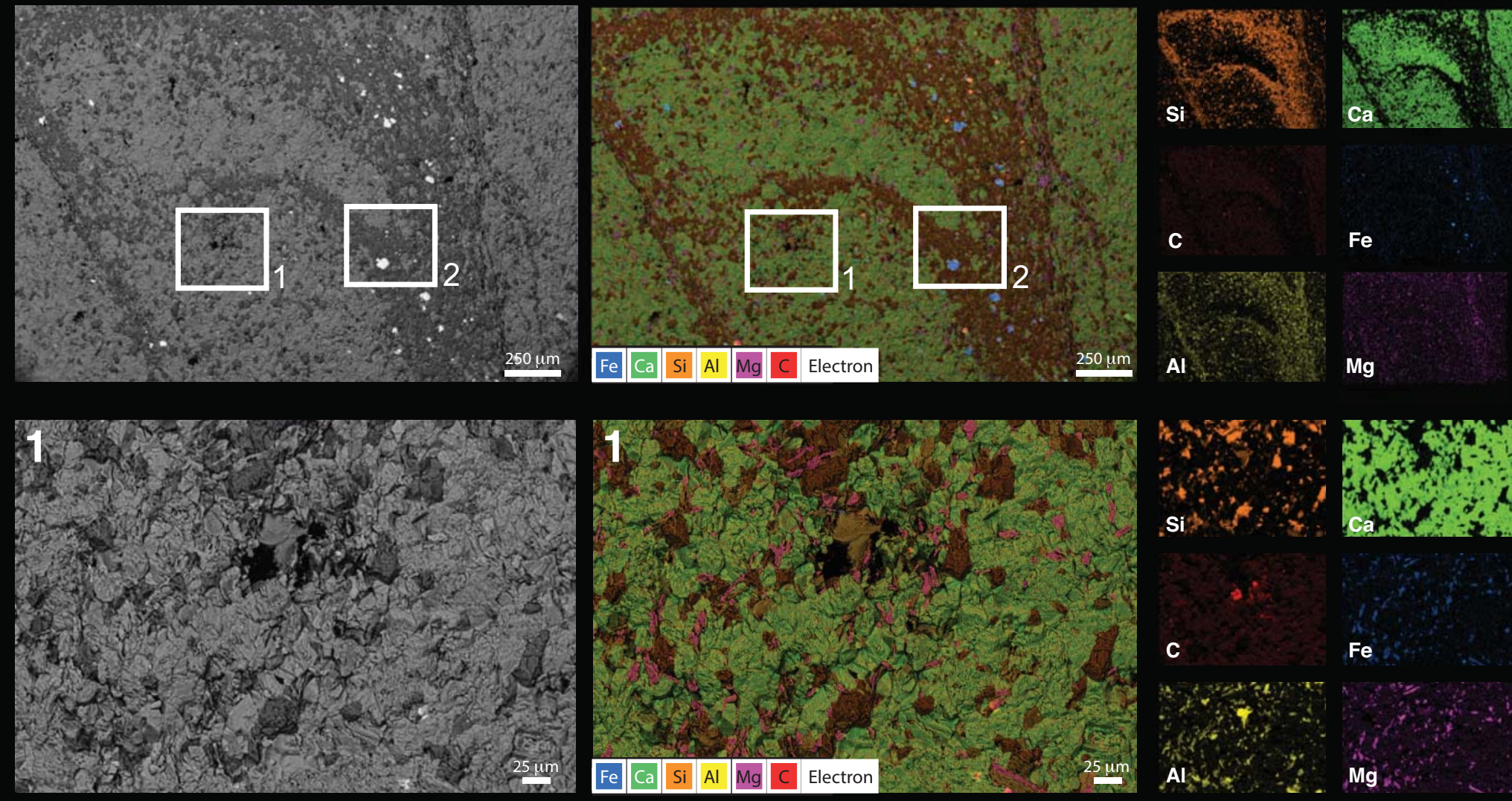

2

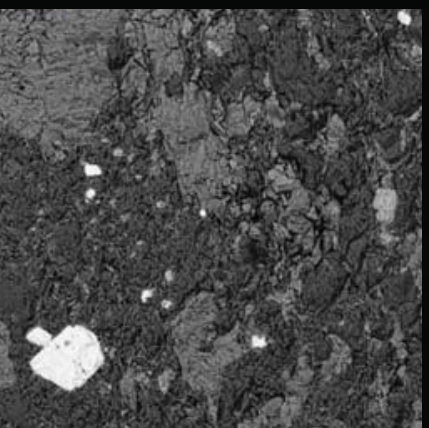

2
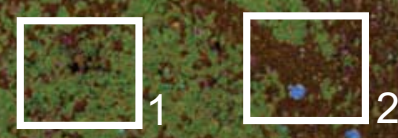

C

$\mathrm{Fe}$

Si

cant 24

c

$8 x^{2} y^{4}-3$

$\mathrm{Al}$ - $\mathrm{Mg}$
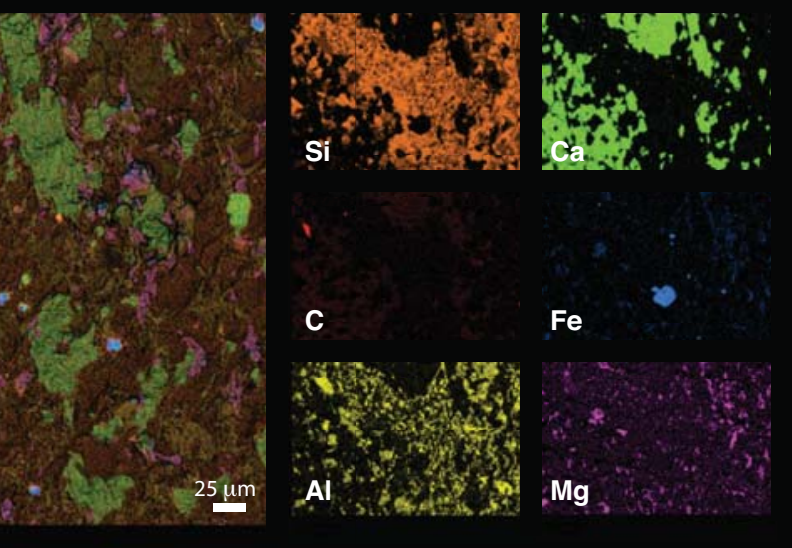